\title{
Escribir como mujer en los albores del siglo $X X$ : construcción de identidades de género y nación en la crítica de Inés Echeverría (Iris) a las puestas en escena de teatro moderno de compañías europeas en Chile
}

\author{
Writing as a Woman at the Turn of 20th Century: \\ Construction of Genre and Nation Identities in \\ Criticism of Inés Echeverría (Iris) regarding Modern \\ Theatre Production of European Companies in Chile
}

\author{
María de la Luz Hurtado \\ Pontificia Universidad Católica de Chile, \\ Facultad de Artes, Escuela de Teatro. Santiago, Chile \\ dhurtadm@uc.cl
}

Resumen - En este ensayo abordo las narrativas de identidad elaboradas por sujetos femeninos en torno a un espacio cultural hegemónico en Chile y Latinoamérica de inicios del siglo XX: el generado por compañías teatrales europeas en gira por países periféricos sujetos a su neo-colonización. Utilizo como textualidad referencial la crítica teatral de una pionera en la escritura chilena: Inés Echeverría (Iris), revelando sus tramas discursivas relativas al género y a lo neocolonial, en cruce con sus posiciones respecto a estéticas dramáticas, de la performance y del cuerpo.

Palabras clave: género, neocolonialismo, construcción del sujeto, performance, drama moderno.

Abstract- This article refers to identity narratives written by female subjects in the midst of a hegemonic cultural space in Chile and Latin America at the turn of the 20th Century: created by European theatre companies on tour in outlying countries subject to neo-colonization. I use as referential textuality the theatre criticism of a pioneer in Chilean literature: Inés Echeverría (Iris), revealing discursive plots related to genre and neo-colonial issues, mingled with her positions regarding drama, performance and body aesthetics.

Keywords: genre, neo-colonialism, subject construction, performance, modern drama.

\footnotetext{
1 Proyecto núm. 1060528 "Género, clase y etnia en el teatro chileno de la primera modernidad: 19001918", financiado por el Fondo Nacional de Ciencia y Tecnología, Fondecyt. Investigadora responsable: María de la Luz Hurtado.
} 
La crítica sería el arte de la insubordinación voluntaria, del infringir reflexivo. ${ }^{2}$ La crítica aseguraría esencialmente la de-subyugación del sujeto en el contexto de lo que podríamos llamar «la política de la verdad».

Michel Foucault, «¿Qué es Crítica?»

\section{IRIS: ¿DESDE DÓNDE PUEDE/QUIERE HABLAR COMO CRÍTICA TEATRAL EN TANTO SUJETO FEMENINO SUB-ALTERNO?}

\section{Escribir como mujer en el espacio público: procesos de construcción de subjetividades corporizadas}

Yo era la única señora bastante osada para romper el silencio forzado de la mujer y, además, tan valiente para encararme con los ministros del Señor.

Inés ECHEverría, Memorias de Iris

En este trabajo, exploraré el tipo de estrategias utilizadas por algunas intelectuales y escritoras chilenas para agenciarse a sí mismas y a lo femenino, y para construirse como sujetos mediante modos concretos de elaborar y exponer su cuerpo textual y social en el espacio cívico-público chileno, a raíz de las performances teatrales europeas realizadas en el país entre 1908-1918.

Me centro en una pionera: Inés Echeverría (1869-1949), quien inició su vida en las letras en 1904, una década antes que la mayoría de las mujeres escritoras chilenas de la generación «feminista» (Nómez, citando a Showalter, 1997: 85), aunque feminismo sui generis, necesario de cualificarse en sus elementos de ruptura y conformidad con lo dominante.

Adelantada de una generación, Inés Echeverría brilló con luz propia, llegando a ser la primera mujer recibida como académica por la Academia de Filosofía y Letras de la Universidad de Chile, en 1925. Así todo, no le fue fácil sacar su voz en lo público desde el silencio, tras tres décadas de matrimonio y ser madre de cuatro hijas de una familia aristocrática.

Con tal raigambre, llama la atención que fuera ella y no otras que no tenían tales condiciones - como Gabriela Mistral- quien desafiara en sus escritos definiciones canónicas de lo femenino, como el matrimonio, la maternidad y la sujeción a la Iglesia Católica, las cuales pocas mujeres de su generación quisieron mover o cuestionar. ${ }^{3}$ En otras ocasiones se relaciona con lo femenino asumiendo el discurso dominante, al que ella da

2 «Reflected infractability». Ésta, como todas las traducciones desde otro idioma al castellano, son mías.

3 «El feminismo chileno entre 1900 y 1940 fue de tipo liberal o doméstico, en el que partiendo de una visión tradicional de sí buscaron la reivindicación de sus derechos civiles y políticos desde una posición no rupturista (fundamentado en) un principio de legitimidad femenina vinculada al matrimonio y la maternidad» (Veneros 199: 59). En la literatura, esta postura se habría manifestado en el uso de una doble voz, en estrategias de subversión en clave que no amagaban directamente dichos valores. En relación a la Mistral, ver Rojo, 1997. 
sorprendentes giros que desafían nuestra perspectiva actual. ${ }^{4}$ Esta tensión en su discurso es propio de las construcciones de género en transición, que entrelazan heteróclitamente diferentes componentes que abrevan desde su medio:

Este reconocimiento de la interrelacionalidad y co-implicación en el género de variadas otras categorías como raza, clase, nación y sexualidad, y uno en el otro, ha hecho posible la redefinición del sujeto femenino [...] como uno menos puro, y por cierto ideológicamente cómplice con «el opresor», cuya posición el sujeto feminista puede ocupar en ciertas relaciones socio-sexuales (aunque no en otras) en uno u otro eje (De Laurentis, 1988: 136).

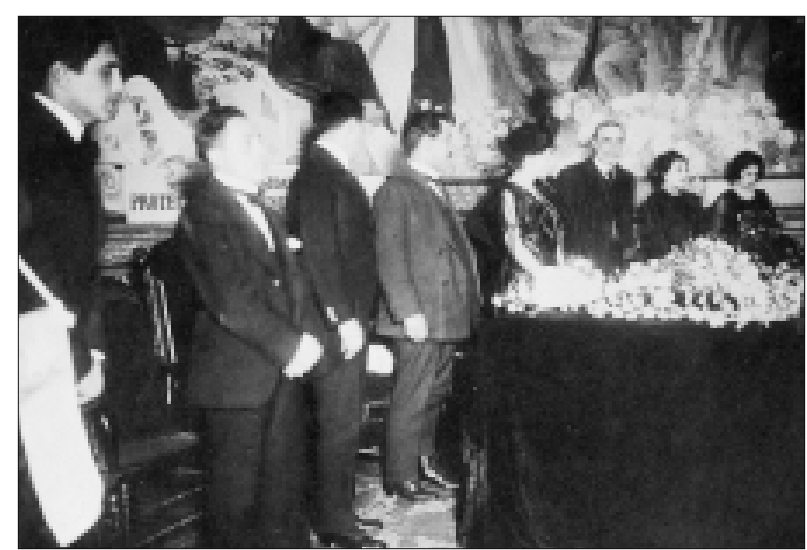

Inés Echeverría Bello en su recepción como Académica, Facultad de Filosofía Universidad de Chile. Santiago, 1925. En Memorias de Iris: $1899-1925 .^{5}$

En dicha crítica, y mediante una mixtura de géneros literarios, a la par que discute las performances y a las dramaturgias, reflexiona sobre diversos ejes de su propia constitución como sujeto corporizado y los de su medio cultural local y nacional, puestos en relación a un continuo referente incorporado/distanciado: lo europeo, en sus distintas vertientes civilizatorias y raciales. De aquí que postulo que, como crítica de teatro, Echeverría desarrolló un discurso tensionado por la alteridad/subalternidad, activando en su reflexión los ejes de género y los neo-coloniales, junto y a partir de una intelección crítica de los lenguajes dramáticos y performativos puestos en escena por europeos en los teatros chilenos de palco de la época. Al vislumbrar a través de Iris la mirada de una porción de la élite cultural que ella agencia respecto a ese teatro europeo representado en Chile, irán revelándose las «condiciones de la modernidad» (Wagner, 1994: 24) chilenas en las que surgió su práctica escritural.

En el terreno de las performances y las teatralidades, el sujeto se remite al cuerpo/ poder, al cuerpo/saber y al cuerpo/deseo, concibiendo al cuerpo no sólo como sede de flujos relacionales sino como cuerpo desbordado que excede el mecanismo referencial del lenguaje (Foucault, 1992). Apuntaré a qué cuerpos concretos entran al juego performativo de estas teatralidades y performances europeas/chilenas; a qué etnias y nacionalidades pertenecen, a cuáles significan o aluden, cuáles son sus extracciones socio-económicas,

\footnotetext{
4 Escribo este ensayo a un siglo de que ella incursionara en la crítica teatral de prensa, en 1908.

5 La toma y edición de fotografías estuvo a cargo de los ayudantes de investigación del Proyecto Fondecyt Loreto Leonvendagar y Gabriel Contreras.
} 
desde qué oficios, habilidades y capacidades expresivas se incorporan al espacio performativo. La presencia corporal de Iris en los palcos del Teatro Municipal en los que aparece a la par como mujer, esposa, miembro de una familia y como crítica teatral e intelectual se inscribe en este ámbito de problemas. ${ }^{6}$

Estos agenciamientos producidos en la construcción discursiva del sujeto femenino se da en juegos de poder, de disciplinamientos, acomodos, subversiones abiertas o encubiertas. Son estos flujos dinámicos los que busco delinear, cuando en este tiempo aún no se había establecido en Chile un canon para el lenguaje público femenino, el cual sufría el peso prevaleciente del masculino y de las prescripciones en relación a lo femenino. Con ello, busco reafirmar la dimensión política contenida en este tipo de discursos, por cuanto:

las lógicas sociales implícitas en las narrativas de la cultura tienen una tremenda fuerza política [...] se requiere enfatizar la relación entre conocimiento y poder, las formas en que el disciplinamiento del conocimiento está implicado en la formación de sujetos sociales (Hennessy, 1993: 11 y 14).

\title{
LOS MODOS DE CONSTRUCCIÓN DE LA CRÍTICA TEATRAL DE IRIS
}

\begin{abstract}
Si entendemos el arte del comediante como una energía primaria del alma humana, que en su proceso vital asimila la literatura y la realidad [...] la interpretación de este arte desemboca en la gran corriente de la comprensión moderna del mundo.
\end{abstract}

GeORg Simmel, El comediante y la realidad

¿Qué tipo de «crítica teatral» realiza Echeverría, entendiendo que esta práctica escritural es transhistórica, por tener un cierto objeto común (la referencialidad a lo teatral por un alguien que lo reflexiona y/o juzga) que es abordado a través de lenguajes y matrices variables, afincadas en cada época y en la posición y perspectiva de quien la practica?

Ella realiza una "crítica inmediata» es decir, «una escritura suscitada por la contemplación directa del espectáculo teatral» (Pérez, 2004:14), para ser publicada en la prensa en los días siguientes al evento. Ésta «revela el universo de la obra» desde el lugar de la recepción, ya que «una obra (teatral) es la revelación de todo tipo de temas, tensiones, fantasmas, marcas críticas» (Berenguer, 1983: 117). De aquí que Pavis (1985: 22) considere a la crítica teatral como parte de las ciencias del espectáculo, realizada a partir de una «semiología inconsciente». En esto, el crítico no está solo: a través de él circulan flujos de poder/deseo que agencian, al concretarse discursivamente, posiciones de otros, quizás aún difusas, animando a su sociedad y actuando como un sujeto multiplicador de su propuesta.

Sus códigos semióticos no necesariamente están en el lugar de lo dominante (como sostengo ocurre con Iris), por lo que provoca adhesiones y también confrontaciones en relación al «horizonte de expectativas» de los receptores de su crítica. Textualidades inscritas primero en la escritura (la crítica), transitan a lo oral mediante la conferencia y vuelven a lo escrito en la contestación y el debate público. En esta cadena de producción de significados,

6 En una línea similar, he explorado la no presencia pública pero sí presencia corporal de Gabriela Mistral en el Teatro Santiago en los Juegos Florales de 1914, negando/confirmando su correspondencia de género/ clase/etnia y, en especial, de poetisa en dicho escenario. 
cada cual ejerce su capacidad interpretativa y la pone en circulación (Giella, 1994: 43). En este sentido, la crítica teatral de Iris anima lo social, generando polémicas y discursividades en disputa: produce choques de agenciamientos de lo femenino y entre lo femenino y lo social, diverso y plural, en este inicio del siglo XX, en agitada transformación.

El desentrañamiento de esta dialéctica de producción/recepción de discursos y textualidades no solo permite develar el universo simbólico individual de el o la crítica (en este caso, de Iris) sino también el campo cultural (Bourdieu, 1995) que lo/la informa y que él/ ella contribuye a con-formar, entrando en el campo de interés de la teoría crítica.

El campo cultural chileno le era adverso a Iris, porque invade un área de la escritura no frecuentada por la mujer, ya que el ensayo y la crítica teatral estaban hegemonizados por la escritura masculina. ${ }^{7}$ De aquí que hubo de desarrollar estrategias de validación de su introducción en la cosa pública desde su condición de mujer, recurriendo a, y formando, sus capitales sociales. Su adscripción a la aristocracia chilena fue ambivalente en su legitimación como escritora. La vertiente católica tradicional la miraba con sospecha y hasta escándalo, ${ }^{8}$ y entre sus más cercanos contravino acendradas ideas y prácticas que excluían a la mujer del ámbito público. A veces distanciada pero nunca rotas sus relaciones sociales y familiares, su pertenencia a la aristocracia no se le pudo negar a la hora de negociar poderes en lo público.

Esta pertenencia se complementaba con la red de relaciones tejidas pacientemente por ella con intelectuales, políticos y artistas de variadas raigambres: mesocráticas, populares, de provincias, manteniendo amistades personales, circuitos de discusión, intercambio de información, extendiendo a través de ella su influencia a variados centros de opinión y poder. Fue una activa animadora sociocultural, movilizando adhesiones y enfrentando y contrarrestando animosidades en su contra.

Diario solvente, plural, "serio", de corriente central, El Mercurio y las revistas ZigZag, Familia y Selecta, ${ }^{9}$ donde solía escribir, la prestigiaban más que la descalificaban. ${ }^{10}$ Echeverría no escribía, como la mayoría de los periodistas de entonces por un sueldo de sobrevivencia y como trampolín social sino para hacer valer su voz y su visión de mujer intelectual y sensitiva en el espacio público, y para conseguir valoración de esta faceta suya, generando interlocución con «hombres que hablasen mi lengua». ${ }^{11}$ Poder y deseo se confundían en ella, urgida por la pulsión hacia la significancia (Kristeva, 1999).

En su libro dedicó sus críticas a familiares, políticos, artistas y periodistas de gran ascendencia, como Eliodoro Yáñez, Luis Orrego Luco o Carlos Silva Vildósola, identi-

\footnotetext{
7 Hasta ahora grandes intelectuales chilenos o avecindados en Chile habían ejercido la crítica teatral, todos hombres; en el último cuarto de siglo XIX e inicios del XX, Rubén Darío, Pedro Balmaceda Toro (A. de Gilbert), Augusto y Luis Orrego Luco, Miguel Luis Amunátegui, Diego Barros Arana, Rafael Errázuriz Urmeneta, Vicente G. Huidobro, etc.

8 Su libro Hacia el Oriente fue indirectamente censurado por el clero y erradicado de las opciones de lectura de mujeres católicas por sus confesores.

9 Al no identificar en su publicación «Emociones teatrales» en qué periódico o revista realizaba sus críticas, y por lo incompleto del archivo de periódicos de esa época de la Biblioteca Nacional, no he podido confirmar dónde publicó dichas críticas. Aunque he constatado que aquellas más amplias y «cultas» eran publicadas por El Mercurio y El Diario Ilustrado, este último, bajo el título genérico de «Impresiones Teatrales».

10 Contrario al caso de Teresa Prats, quien por necesidad económica escribió sobre temas literarios, sociales y filosóficos en La Ley, periódico excomulgado por el arzobispo, quedando estigmatizada como herética (Echeverría, 1905: 178-9).

" «Cambié a las comadres de barrio, que cuentan historias menudas y caseras, por hombres que hablasen mi lengua» (Echeverría 2005; 159 y 177).
} 
ficados como "amigos», por tanto cercanos afectivamente y con lealtades recíprocas. ${ }^{12}$ ¿Estrategia de inscripción en el poder para suplir su falta de posicionamiento en tanto cuestionada mujer literata? Sus dedicatorias tienen una doble clave, ya que da referencias incompletas sobre el aludido (solo las iniciales) y este es elegido por coincidir con el tema, conflicto, personajes, crisis que se devela en la obra comentada.

Iris no es parte del equipo de redactores del diario ni participa de sus rituales, sociabilidad, modos de ejercer el oficio: no es una periodista "profesional» ${ }^{13}$ ni tampoco trabaja en la redacción del periódico sino en «su cuarto propio». Igual cumple la exigencia agotadora de publicar al ritmo de los estrenos, de cuatro a ocho críticas por compañía. ${ }^{14}$ Tampoco va a platea o a galería con otros críticos, ni el periódico le paga la entrada o le da pase libre para ejercer su oficio. ${ }^{15}$ Echeverría va con su esposo a su palco privado del Teatro Municipal de Santiago, lugar en que se presentan todas las obras criticadas por ella: temporadas de las compañías españolas María Guerrero (1908-9), Tallavi (1909), Thuillier/Pino (1910), y de la italiana Clara Della Guardia (1909). Allí participa del ritual de saludos, visibilidad panóptica, visitas de palco a palco, comentarios y discusiones sobre la obra u otros temas candentes (Hurtado, 2007).

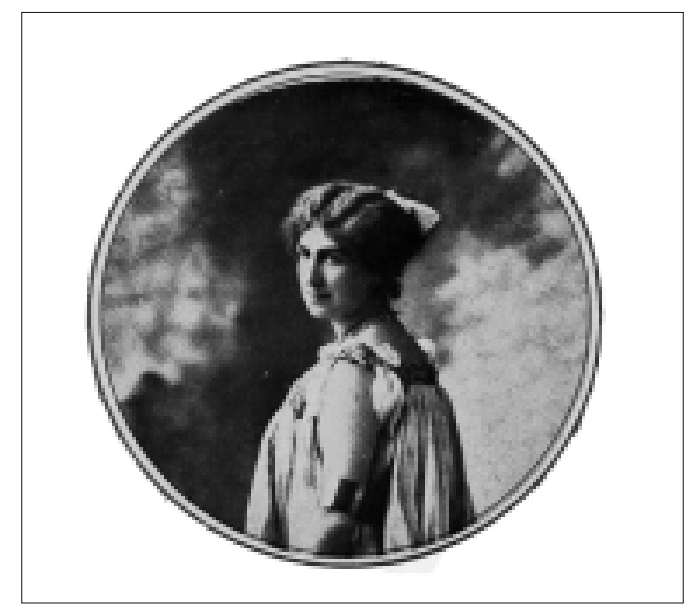

Inés Echeverría en Roma (1901). Reproducida en revista Zig-Zag 60, 1906.

Asiste cumpliendo a cabalidad la «obligación de la belleza femenina» en dichos palacios de la omnipotencia burguesa que son los teatros de palcos: es prioritario para ella completar su lujoso atuendo, ponerse las joyas y los aderezos correspondientes, ayudada por una «vestidora", la que con su mirada desaprobatoria, establece la situación de otre-

12 Aparte de su tía-madre, solo una mujer es agraciada con su dedicatoria, no casualmente, en su crítica a Casa de muñecas, de Ibsen.

13 En las fotos de los muchos actos de homenaje, banquetes, celebraciones de los periodistas nunca aparece ella ni otra mujer como miembro del grupo de redactores, siendo que habían muchas que ejercían el oficio.

14 «Desde hace cuatro noches ha comenzado mi tarea teatral. Y digo tarea pues el ayuno de arte en Chile me produce un hambre que me obliga a empacharme. Las buenas compañías vienen raras veces y se quedan pocos días. Voy todas las noches, escribo mis impresiones y me quedo exhausta. Hago un curso artístico forzado por el tiempo escaso" (Echeverría 2005: 367).

15 En este tiempo ejercía una pléyade de críticos, por la gran cantidad de revistas teatrales especializadas y de periódicos existentes, y la centralidad de lo teatral en la vida socio-cultural. 
dad radical de género y clase en que se encuentran. ${ }^{16}$ En una oportunidad, por la demora en vestirse, perdió más de un acto de la obra teatral a criticar.

Su doble poder de aristócrata y crítica de teatro le permitió franquear barreras vedadas a otros, como irrumpir en el camarín de la diva María Guerrero en un entreacto para manifestarle su emoción. La frialdad de la actriz le aclaró que se había excedido en sus prerrogativas, asentadas en el poder local, que no atañían a la Guerrero.

Iris, como hablante y sujeto de la narración, asume en sus críticas su posición contingente, corporizada en el espacio/tiempo de la sala de teatro inmersa en la ciudad, la nación, el mundo occidental. Percibe atmósferas, interpreta deseos del público en cuanto a desarrollo de la trama o modos de actuación, recoge impresiones de otros y otras, los evalúa, contextualiza y contesta. Se establece como mediadora, como interlocutora en actitud dialógica con el público que circula en torno a ella y que la lee. ${ }^{17}$ Por tanto, si bien su crítica tiene alcances transversales en lo social por la cualidad de discurso analítico, discernible y apreciable por amplios lectores ilustrados, hay una dimensión de su discurso que permanece en el circuito endogámico de ese «riñón aristocrático» en lo social e intelectual al que pertenece. Se encuentra en un «entre-medio», en la incapacidad de elaborar en plenitud un discurso público, en los términos de Habermas (1999), quien establece como criterio básico la interlocución transversal en lo social e ideológico.

El título Emociones teatrales con que Iris denomina su libro indica que la emoción provocada por la obra en el espectador era un criterio estratégico para dilucidar la cualidad artístico/dramática de la obra, emoción que no excluye la dilucidación lógica o analítica ni es atributo privilegiado sólo desde lo femenino. Su cualidad de valor generalizado a la época entre los «espiritualistas de vanguardia» (Subercaseaux, 2001, 26) es confirmado por la teorización del escritor y también crítico teatral Eduardo Barrios (1916):

Para mí, el arte es una ficción que sirve para comunicar, no la verdad misma, sino la emoción de la verdad [...] de las verdades estéticas de las almas, de los actos humanos y sus procesos, de los paisajes, de las cosas. La emoción estética no es otra cosa que una perturbación que nos exalta. Y desde la blanda sensación hasta la exaltación delirante y loca se desenvuelve el camino de la perturbación. [...] El máximum de perturbación en el lector o espectador marca el máximum de arte en una obra. Luego, como los extremos se tocan, resulta que el sumum de locura va del brazo del sumum de razón: el genio (sin numeración).

Este tipo de crítica no adscrita a un marco teórico ni a un método sistemático se suele denominar «impresionista»: al referirse a su práctica crítica, Iris dice estar consignando las «impresiones» que la obra le provocan. De hecho, la columna de El Diario Ilustrado de crítica teatral a la fecha se titulaba «Impresiones teatrales». Iris se pone así en actitud de exponerse como sujeto a ser impactada en lo emotivo y reflexivo por el espectáculo y su entorno, dejando en la escritura la huella que estos imprimen en su cuerpo y subjetividad. De aquí que, aun cuando al inscribir sus textos en el plano de las «emociones», no corresponde a la mujer «lectora sentimental» sino a la mujer «lectora crítica» (Oyarzún, 1992: 43). La intuición perspicaz, el estilo elegante, fluido, un tanto irónico, son caracte-

16 «Creen que voy al teatro a descansar o a divertirme. La sirvienta que me viste, una beata a quien los escrúpulos han contraído el rostro, me pasa el vestido y las joyas con aire de encomendar a Dios mi alma extraviada» (Echeverría 2005: 367).

17 En palcos y salones de foyer, con acceso diferenciado a los espacios más económicos y masivos de galerías $\mathrm{y}$ segundo y tercer orden. 
rísticos de su lenguaje. Al incluirse en, y establecer, un circuito de referencias sociales y culturales con el receptor, genera un tono de cierta intimidad y complicidad, en especial con las mujeres, aun cuando las opiniones críticas suelen ser tajantes, posicionándose con autoridad frente a lo dicho.

La textualidad crítica de Iris se instala en la fisura de géneros literarios referenciales, que transitan entre la crónica, el testimonio, la confesión, el ensayo. Este último, en tanto en su teorización estética emplea hipotextos teosóficos y morales, donde pone en juego su erudición culta de referentes literarios, filosóficos, sociológicos en un recorrido de autointerrogación y búsqueda de sentido. El que el discurso de Iris, al modo de los discursos transhistóricos y transgenéricos como la crítica y el testimonio (Morales, 2001: 24-5), establezca un vínculo indisociable entre su identidad en construcción como sujeto social, subjetivo y cultural desde tanto una sensibilidad «emocional» como un recorrido analítico de la obra teatral europea puesta bajo su mirada considerativa, conduce al establecimiento de anclajes y redes relacionales con lo extra-textual desde, para y con el cual ella habla/escribe. Esto la pone en una situación vulnerable y expuesta, ya que su persona, mediada e in-corporada en su discurso, queda plenamente implicada con las redes de poder y saber de su tiempo. ${ }^{18}$

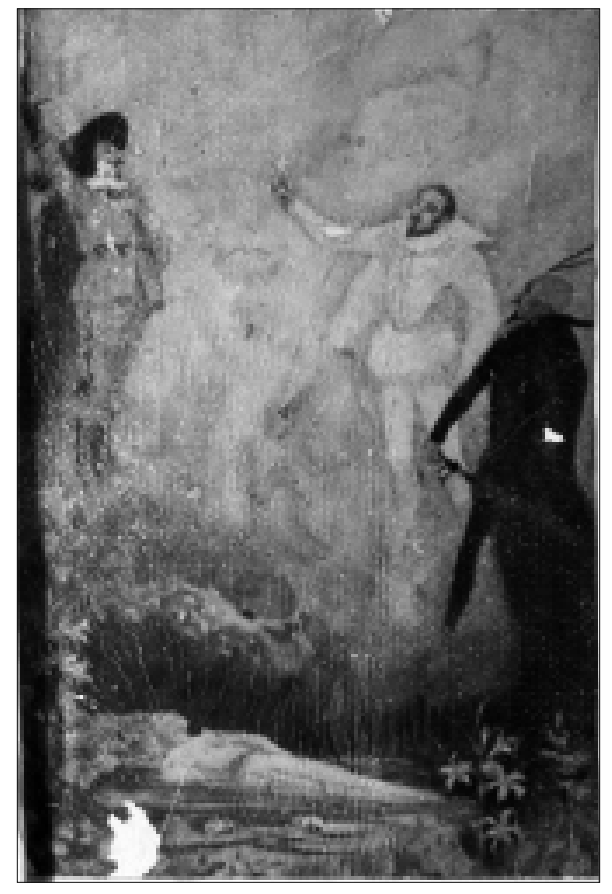

Pintura con personajes y autores teatrales en portada de Emociones Teatrales de Iris.

El modernismo finisecular trajo consigo la diversidad estética: explosionan los lenguajes en la medida que se triza la confianza en la modernidad como proyecto utópico, provocando un «desencanto del mundo»: «la razón ilustrada burguesa en su plasmación

\footnotetext{
18 A pesar del uso del pseudónimo, que no era un subterfugio de ocultamiento sino uno de empoderamiento hecho visible y plenamente descifrable en su entorno.
} 
real estaba plagada de contradicciones y era portadora igual de progreso que de destrucción» (Picó, 1992: 16). De una cierta univocidad de los siglos anteriores, desde la segunda mitad del siglo XIX se multiplican las vertientes estéticas dentro de una misma disciplina las que, por inéditas y por su radicalidad, entusiasman al público, aun cuando sean contradictorias entre sí. De aquí que Iris se vea enfrentada a identificar y discriminar entre las diferentes corrientes prevalecientes en el teatro europeo que desembarcó en tierra chilena (teatro clásico, psicológico, realista, naturalista, simbolista...), las que entretejió con un modo particular de situarse como voz de la enunciación (femenina), incluyendo sus diferentes adscripciones de pertenencia nacional periférica, filosófica-religiosa, aristocrática, de construcción de género, etc.

Iris despliega en plenitud una metodología crítica que aún hoy en día —en que vivimos en Chile una notable y patética jibarización y empobrecimiento de la crítica teatral periodística- es consistente con la inextricable relación texto dramático/puesta en escena. Ella va recorriendo la trama de la obra, la acción y las transformaciones de ésta en y a través de la situación del personaje, en confrontación con la construcción escénica que va realizando el actor en toda su variabilidad y tensión dramática, y, al ponerse como sujeto receptivo de dicha acción dramático/actoral, alude a la reacción emotiva y comprensiva que lo anterior provoca en el espectador. Es decir, produce una dialéctica entre la acción poética (del texto), la acción de la representación actoral (la dimensión performativa) y la proyección de las anteriores en el espectador (de conocimiento y animación de pasiones), a través del procedimiento de ponerse a sí misma como espectadora privilegiada. ${ }^{19}$

Esta práctica escritural suya, al transitar desde esporádicas críticas de prensa a un libro, Emociones teatrales, publicado por una prestigiada editorial como lo era Barcelona, la validan en tanto productora de una obra literaria autónoma de la coyuntura, con un corpus intertextual animado por una voluntad y una práctica propiamente autoral. Así, y por su cualidad de género referencial con elementos emancipatorios procedentes de un sujeto subalterno en términos de género (femenino) y posición (periférica) dentro de lo neocolonial, permite que por esta escritura "pueda transitar ‘también` (y no sólo por la poesía, la novela o el drama) las grandes peripecias de la historia del sujeto, los grandes temas de la cultura, e incluso, por qué no, los grandes modelos estéticos» (Morales, 2001:12), lo que postulo se realiza plenamente en la crítica teatral de Iris.

\footnotetext{
19 Esta es una práctica innovadora. Los críticos distinguidos que precedieron a Iris en Chile no realizaron esta dialéctica: Rubén Darío, en sus críticas en Chile a la Bernhardt en el Diario La Época, dio impresiones generales y subjetivas, centrándose principalmente en la actriz para, desde ella, evocar poéticamente a lo femenino. Pedro Balmaceda Toro realizó una drástica distinción entre análisis del texto dramático y de la puesta en escena, publicados en días y columnas diferentes. Igual procedimiento usaron los críticos del movimiento teatral universitario en la década de 1950, que no imbricaban ambas textualidades.
} 


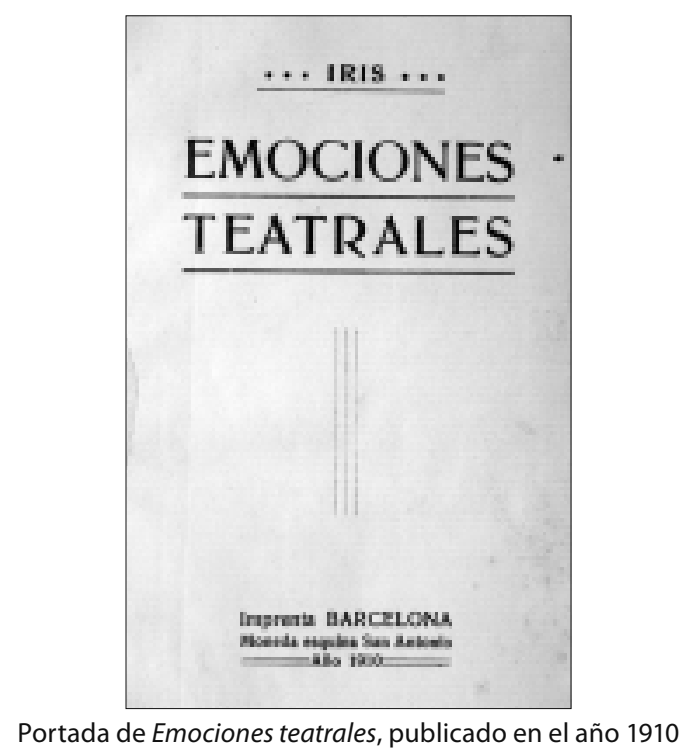

En lo que sigue, sistematizaré los criterios críticos, las principales tramas discursivas y los recursos textuales urdidos por Echeverría/ Iris en sus críticas a las temporadas de teatro europeo en Chile reunidos en Emociones teatrales (1910), apuntando al modo en que establece un dialogismo social y cultural con su medio en ese Centenario chileno. Buscaré identificar su mirada de identidad/otredad que articula al género con la nación, la clase social, la etnia, el modo de pertenencia y distancia respecto a «los dos mundos» en que dice debatirse: la tradición decimonónica/la modernidad del siglo XX; lo europeo/lo chilenolatinoamericano; lo histórico y material (lo real)/lo trascendente (lo espiritual). También, sus modos de comprensión y apreciación de los géneros y estilos dramático-teatrales a los que se enfrenta como crítica, en una tensión entre lenguajes dominantes y de vanguardia.

\section{DE LA CONSTRUCCIÓN DEL GÉNERO:}

\section{Ejercicio crítico-teatral desde la conciencia moderna del «yo» en proceso de construcción de lo femenino}

¿Qué diferencia hace quién esté hablando? Michel Foucault, "What is an Author?»

Iris elabora un discurso crítico desde múltiples vértices, en un juego de ida y vuelta desde la ficción dramática y el imaginario espectacular a la construcción del sujeto (femenino) en la historia.

No intenta someterse al modelo de la razón y al academicismo sino desarrolla con libertad y confianza su propia voz desde lo femenino, reivindicándola como superior, 
o al menos, diferente a la masculina: «Al correrse la cortina, las mujeres sentimos un profundo descanso, porque nuestra sinrazón es la razón de la vida... y con eso basta para triunfar definitivamente» (Iris, 1910: 119). «Sinrazón», argumento que utilizó la Ilustración para excluir por más de un siglo a la mujer de lo público, con el supuesto de que su pensar y actuar desde la emoción y el afecto introduce un «desorden» inaceptable en dicho espacio (Pateman, 1989). Paradojal auto-sustento de Iris en un discurso fuera de la razón, siendo que su articulación textual expositiva se vertebra en hipótesis interpretativas y argumentaciones que aúnan con coherencia interna los elementos de su discurso.

Iris, ni probablemente ningún crítico de su tiempo, hablaría desde una tercera persona neutral. Ella habla desde su seudónimo/heterónimo Iris, esa "otra» de sí misma, que en su simbología teosófica significa «paz después de la tormenta» o «liberación de femenina esclavitud» (Echeverría, 2005: 238). Desde esa posición de mujer liberada que tras sufrimiento personal ha logrado su centro, propone que su escritura es también para ella un modo de explorar su subconsciente. ${ }^{20}$ Se relaciona con el objeto criticado desde una perspectiva de género, reconocida y reivindicadamente femenina, positivando aquellos rasgos que el ideario patriarcal, ya convertido en sentido común en ese medio, califica como la debilidad femenina: «Es inútil pensar cuando sentimos» (Iris, 1910:146).

Incluso, se refiere a dimensiones asociadas a lo femenino consideradas como frívolas y mundanas, aunque también frecuentadas por cronistas y ensayistas hombres: ${ }^{21}$ «Pero antes de continuar, me escudo en el privilegio de ser mujer [...] para darme el gusto de hablar de trapos» (Iris, 1910: 109). Para ella, la belleza femenina es un triunfo sobre lo masculino, ${ }^{22}$ acorde con la construcción de género dual realizada en Occidente desde la Ilustración y la Revolución Francesa.

$\mathrm{Al}$ avanzar en el cuerpo de este texto crítico, Iris incorpora esta consideración a la interpretación de El ladrón, de Berstein, para entender el sentido profundo del comportamiento de la protagonista femenina encarnada por María Guerrero:

[María Guerrero] coge en seguida un precioso kimono color fresa que se armoniza con la decoración del cuarto y nos da la emoción completa de la mujer francesa tan provista de dones naturales, tan exquisitamente dotada para continuar la tradición de la Madre Eva (Iris, 1910: 111).

20 «La pluma que tomé por primera vez para traducir esa tumultuosa vida interior que bullía en mí y para desahogar mi vibrante emotividad ha sido el puente levadizo que me dio paso al subconsciente [...] por el subconsciente que mi pluma extrae, he vencido al tiempo" (Echeverría, 2005: 114), aludiendo a un recorrido libre por las configuraciones problemáticas de la psiquis.

${ }^{21}$ Desde la glorificación del dandy por Baudelaire, los intelectuales y artistas solían realizar crítica de moda y de vestuario como expresión de su sensibilidad refinada, original, moderna.

22 «Las mujeres nos sentimos en nuestro elemento y miramos a nuestros maridos con cierto desprecio porque no pueden usar cosas tan lindas y tan finas, y sus cuellos tiesos nos parecen en armonía con su dureza de carácter tal como nuestros encajes van con nuestras íntimas delicadezas y ternuras» (Iris, 1910: 112-3). 


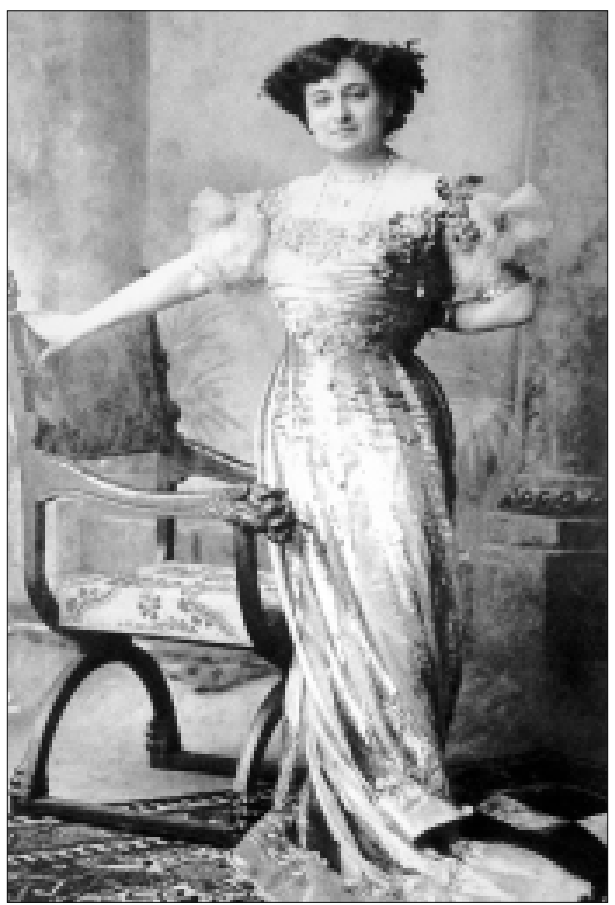

María Guerrero en 1908, revista Sucesos. Santiago. Fotografía de Weth y Vera.

Esta mujer-Eva es quien, en la obra, privilegiando su sensualidad y voluptuosidad femenina, viola las normas sociales (es cómplice de un robo) para realzar y concretar sus necesidades de mujer-serpiente. En el plano amoroso, la mujer tiene el poder y hace del hombre su vasallo, concordando con el mito de la mujer fatal, de la Salomé, ${ }^{23}$ reeditada en ese tiempo en múltiples versiones literarias, teatrales, de artes visuales, cinematográficas, y que da cuenta de una dimensión de la emancipación femenina tratada en forma altamente ambigua. Contra el concepto decimonónico de que el hombre es activo y la mujer pasiva, "modesta» en su cuerpo y deseo, se contrapone esta mujer, recuperada desde el mito clásico, sujeto del deseo, y que la exhibición de sus dotes para lograr la consumación de su sexualidad y erotismo es irrenunciable de su ser. ${ }^{24}$

Iris, desde su propia sensualidad femenina, capta y apoya esta dimensión de la obra, cambiando el eje de la posible mirada moralista y condenatoria a la protagonista delincuente hacia una comprensiva y empática. ${ }^{25}$ La identificación cuerpo a cuerpo con esa

23 «Dentro de esa fuerza, que es el secreto y la esencia misma de la vida, la mujer se siente dueña del hombre, lo hace su inferior, su vasallo y su esclavo!» (Iris, 1910: 117).

24 Peter Wollen (1995: 84-86) propone que esta recuperación del mito de Salomé y de la mujer serpiente es parte de la emancipación de la modernidad, ligada al nacimiento del psicoanálisis, y que, desde los decadentistas en adelante, habría puesto en duda la binariedad femenino/masculino en relación a un polo activo (el hombre) y uno pasivo (la mujer). Al disolver dicha oposición, se liberarían fuerzas en lo femenino y también en lo masculino.

25 De hecho, los chilenos Hederra («Vencido»y «Gregorito») y Armando Moock («La serpiente»), realizan similar caracterización de lo femenino, pero cuestionan moralmente a ese tipo de mujer, considerándola la perdición del hombre (de su economía, el uno, de su razón, el otro). 
mujer en escena, con el roce y tono de las telas y su armonización con el conjunto, en el despliegue de la coquetería y la conquista por el amor, es lo que sólo ella y las mujeres como ella podrían captar como núcleo de ese drama:

Quedó perfectamente puesta de relieve una verdad humana: la mujer lo sacrifica todo al amor [...] y si llegado el caso no pasa por encima de las convenciones, es porque no ama! ¡Dentro de esa fragilidad aparente, está actuando la vida, que tiene siempre razón de la sinrazón social! (Iris, 1910: 118).

La fragilidad aparente de lo femenino es su fuerza superior. Al reivindicar tal punto, Iris usa un "nosotros», ubicándose dentro del grupo de las mujeres frente al de los hombres, y con ello, agenciando flujos de complicidad con sus lectoras mujeres:

Del lado del hombre está toda la lógica, y del lado nuestro toda la debilidad de los razonamientos [...] porque nuestras razones verdaderas derivan siempre de nuestro corazón que tiene razones que la razón ignora — pero que siempre son más altas, más profundas y más trascendentales, puesto que el corazón es una antorcha que toma su luz más allá de nuestras ideas conscientes (Iris 1910: 113-4).

Iris reconoce la propia subjetividad como base de su hermenéutica, no autorreferida sino en intersubjetividad con el "otro» y «la otra», vínculo postulado como una necesidad del ejercicio del conocimiento desde el cual ella se desnuda entera. En ese «entre medio" generado entre dos miradas, entre un apenas vislumbrarse como mujeres desterritorializadas por la sociedad de su ser interior, de su intimidad, ella advierte el fondo de dolor y soledad que existe entre las mujeres que se desenvuelven como pura apariencia en la modernidad. Al decir de Nietzsche, según Picó:

el fenómeno del hombre moderno ha llegado a ser totalmente apariencia: no se hace visible en lo que representa, sino que más bien se oculta tras esta representación. Con esto se erosiona ese lugar de posible seguridad que es la interioridad del yo (1992: 18).

Iris está dispuesta a realizar ese develamiento de la obra artística, que pone a la realidad «entre paréntesis» para aludirla desde su interior; ella realiza en su crítica el ejercicio del autodevelamiento, interpretando la experiencia homóloga pero silenciada de sus pares femeninas. El camino de esta percepción cognitiva es la «sensibilidad de la equivalencia»:

Existe un dolor que yo descubro por donde quiera que voy - ya que cada cual tiene la sensibilidad de la equivalencia, es decir, que sólo somos capaces de apercibirnos en los otros de aquello mismo que llevamos dentro (Iris, 1910: 222).

Misma relación de «sensibilidad de la equivalencia» ocupa en relación al actante dramático, buscando desentrañarlo como «otro» para, en ese movimiento, desentrañarse a sí misma en su identidad más oculta y misteriosa. Lo distintivo de la mirada de Iris es que esa sensación de equivalencia con otros y otras, al mismo tiempo que pone el acento en lo colectivo, en una identidad grupal, reconoce como fuerza originaria y destino de 
esa comprensión sensible del mundo a su individualidad, al trabajo y elaboración de su identidad como «yo» más íntimo y único.

Ese eterno secreto que constituye nuestra individualidad y que cuando era yo muchacha me hacía exclamar: ¡Hay un rinconcito de mí misma donde no ha entrado nunca nadie!... Ese huequecito inviolable constituye nuestra persona, si tuviera semejante dejaría de ser "yo»!

(Iris 1910: 61).

Coincide en esto Levinas, quien considera que la imagen estética desclausura el tiempo ético de la narración al poner a la realidad entre paréntesis y ver la interioridad desde afuera, «introduciendo en el corazón de la subjetividad una referencia radical y anárquica al otro que en realidad constituye la interioridad del sujeto" (citado en Bhabha 1994: 15-6). En este sentido, Iris se integra a ese largo proceso de construcción de la subjetividad moderna que Foucault (1997) rastrea, ligado al escudriñamiento de sí mediante las operaciones y maquinarias de lenguaje, a veces, en la fórmula de la confesión. La psicología como ciencia ya estableció en este inicio del siglo XX su sitial de legitimidad al reivindicar a lo psicológico como elemento constitutivo de la complejidad del sujeto moderno. Un teórico de la modernidad como Simmel ya lo afirmaba en esa época: «como en el arte [...] es posible relacionar los detalles y superficialidades de la vida con sus movimientos más esenciales y profundos», siendo estos movimientos «los vínculos con los estados emocionales y psicológicos. [...] La esencia de la modernidad como tal es el psicologismo» (Picó, 1992: 23).

Esta recurrencia a la psicología es atingente en el caso de Iris, ya que parte de las obras que critica corresponden al género dramático del realismo psicológico como también al del simbolismo, el cual hunde sus raíces en la psiquis y en los arquetipos del inconsciente.

Iris, al tener nítida conciencia que su mirada crítica e interpretativa se realiza desde su condición de género, clase y etnia, no aspira a proveer en su escritura una totalidad (im) posible de develamientos. De una parte, porque la segmentación de oficios, acceso a los espacios públicos, habitus, mentalidad y tipo de "gastronomía del ojo» (Balzac, citado en Sennett, 2002: 357) que existe entre hombres y mujeres en esa cultura de espacios excluyentes entre los géneros la inhabilitan a manejar los códigos de desciframiento del «otro» masculino. Al tener la mujer restricciones en su recorrido por los vericuetos de lo real, ${ }^{26}$ hay un fragmento grande del mundo que se le escapa:

Me convencí de que las mujeres no tenemos ocasión de observar a los hombres, al margen de nosotras mismas, en sus actuaciones masculinas. Nuestra situación es desventajosa, aun en lo que se refiere a psicología respecto del otro sexo. Se nos niega derecho a la simple observación, y a mostrar nuestra propia sensibilidad, tan diferente a la masculina provocativa (Echeverría 2005: 64).

Mujeres excluidas de los múltiples espacios de trabajo y sociabilidad masculina; mujeres reprimidas en mostrar su sensibilidad erótica/sensual cuando interactúan con los

26 No hay mujeres flaneurs, oficio que constituyó a muchos escritores, como Baudelaire, base de su capacidad de dar cuenta de la volatilidad de la urbe moderna, ni mujeres militares ni políticas... 
hombres; entonces, mujeres inhabilitadas para establecer intersubjetividades en diferentes planos con ellos. Su conclusión es de una agudeza extraordinaria: cuando reflexiona sobre la diferencia radical con que ella, en comparación con su marido, ha descifrado social y humanamente a un oficial italiano con que ambos compartieron viaje, dice: «no lo ha mirado con ojo femenino, sino con el suyo de varón fuerte y elevado. Los juicios completos son bisexuales» (Echeverría, 2005: 64; el destacado es mío).

En concordancia con la filosofía binaria vigente a la época, ${ }^{27}$ Iris sostiene interpretaciones duales en relación al género, en la conformación de lo femenino mismo y en su oposición a lo masculino. Basaré esta constatación en su crítica a Casa de muñecas, de Ibsen, escenificada por la Cía. Clara Della Guardia en 1909, uno de los textos críticos más polémicos y de mayor elaboración que Iris realizó entonces. Dice en relación al personaje de Nora:

Las escenas del drama van esculpiendo aquel carácter de mujer que vive su doble vida en profundos contrastes de profundidades y ligerezas. [...] Hay en ese rasgo honda psicología de lo que constituye la dualidad de la naturaleza femenina, en que se mezclan grandezas y pequeñeces, vuelos de águila con caídas de niño (Iris, 1910: 226 y 229).

Esta presentación en Chile de Casa de muñecas, a tres décadas de su estreno europeo (1879), aún expresa esa cultura decimonónica que Sennett (2002) describe tan acertadamente: una sociedad burguesa que sitúa a la mujer en la obligación de la modestia, lo que incluye la supresión de la manifestación en público de sus emociones. La consecuencia es una represión corporal/emocional pauteada por estrictos códigos sociales, que suele llevarlas a graves crisis psíquicas, entre ellas, la histeria. Ante la falta de transparencia y visibilidad de su ser interior, el teatro y la escena habrían hecho visibles lo que la calle (y el salón) esconden en los últimos repliegues de la intimidad. Así lo entendió Iris:

La obra [...] dio forma en el teatro a la historia recóndita pero frecuente que se vive en el alma de tantas mujeres, oprimidas por la vulgaridad del medio, aplastadas por prejuicios, esclavizadas por convencionalismos que las convierten en tantas otras mujeres de salón (Iris, 1910: 219).

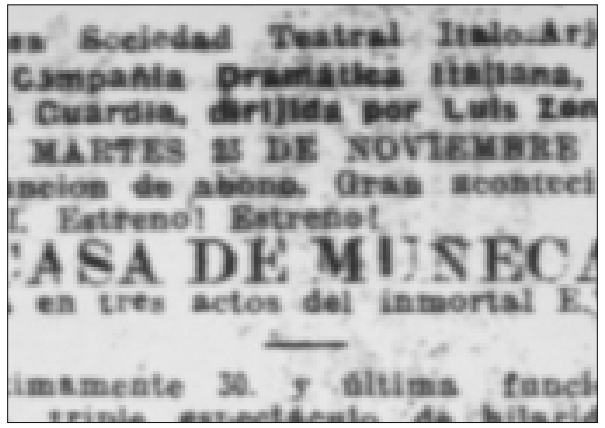

Anuncio de Casa de muñecas en diario El Mercurio, 22 de noviembre de 1909.

${ }_{27}^{27}$ Diferente a la actual que construye la realidad desde redes y conexiones múltiples y rizomáticas. 


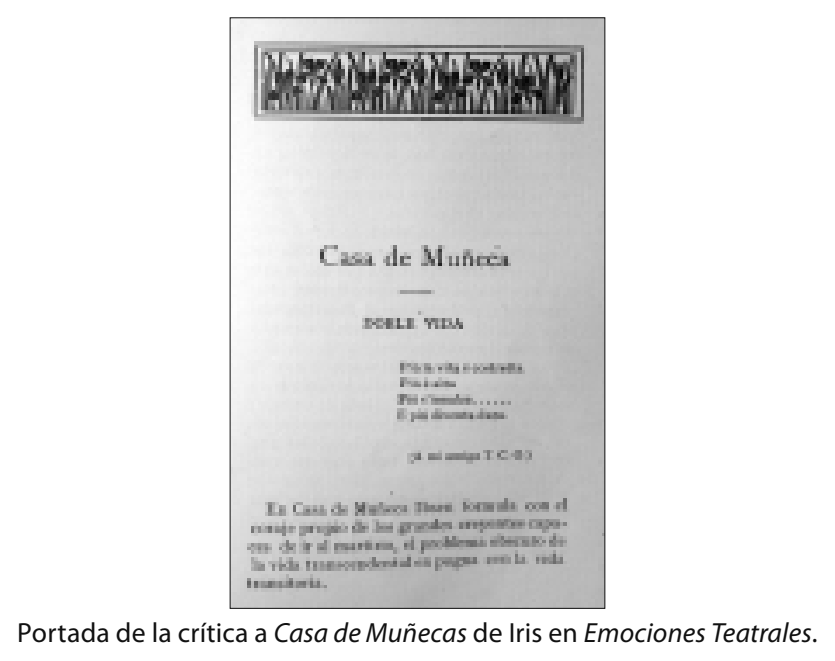

Ve ella dos planos de existencia en lo femenino: la del salón sería su lado aparente, más no entendida como apariencia nihilista tras la cual no hay más que una concha vacía al decir de Nietzsche, ${ }^{28}$ sino esperanzadoramente, en concordancia con su ideario teosofista: la apariencia esconde la faz oculta de la mujer, la que está más arriba (superior) y más adentro, sin luz: ${ }^{29}$ es su reserva clandestina, oculta y reprimida. Forma luego Iris una relación contradictoria, de alta tensión dramática, entre déspotas (lo masculino y sus ámbitos de poder en el espacio público) y las mujeres, las que luchan por, o han logrado, liberarse de estas amarras, cuya «natural intuición alcanza altas cumbres espirituales».

Esas pobres criaturas [...] están viviendo, sin embargo, más arriba y más adentro de lo que jamás imaginan sus déspotas opresores. [...] La mujer, cuando no está encadenada de alma o emparedada de corazón, alcanza en su natural intuición tan altas cumbres espirituales, que se incapacita por eso mismo para sentir o comprender lo que el hombre llama sus grandes problemas, ya sean nacionales, políticos o económicos (Iris, 1910: 219).

En otras críticas, Iris reitera esta postura, cuyo dualismo en la construcción del género convierte a lo femenino y lo masculino en irreconciliables, en pugna y lucha constante. El hombre tiene el poder (es déspota), capaz de encadenar a la mujer en su corazón (encarcelarla). De ser ella más fuerte, desde su intuición (fuente «natural» del poder femenino, de una constitución diferente a la razón y al logos) navegará en esferas que no se encuentran ni comprenden con el habitus masculino. Así, Iris sostiene la confrontación como la dialéctica inevitable entre lo femenino/masculino, en virtud de esta su diferencia esencial: «Benavente, con verdadera psicología del corazón humano, ha hecho una pieza [Rosas de otoño] que marca las distintas esferas en que actúa el hombre y la mujer — diversidad que da origen a la incomprensión que los divide y que los empeña en eterno duelo» (Iris, 1910: 269).

\footnotetext{
${ }_{28}$ Y también, luego, Genet, quien postula que detrás de la máscara está el vacío, entendiendo al personaje (y al individuo) como pura representación.

29 Es el «continente negro», según conceptualizó Freud a la mujer.
} 
Iris es ambivalente en relación a cómo la mujer ha de comportarse en este «eterno duelo» (por tanto deshistorificado: es y será así por todos los tiempos, por cuestión de naturaleza). En Rosas de otoño, comparte la premisa de Benavente de que la esposa fiel y abnegada debe sufrir en silencio las calaveradas del marido, obteniendo a la postre su triunfo: el amor del alma prevalecerá. En múltiples ocasiones, valoró y hasta homenajeó a mujeres que supieron y pudieron callar, replegándose al interior o subordinándose a sí mismas ante la potestad y/o despliegue del marido. Aunque esta actitud del personaje está reñida con su propia práctica y lucha, no critica el punto de vista del autor sino que sigue su lógica demostrativa, propia de una dramaturgia de tesis moral.

Aun así, ocupa con énfasis su pluma y argumenta decididamente cuando dicho «eterno duelo» conduce a la ruptura de la relación hombre/mujer, cuando el ejercicio despótico del primero coarta la libertad interior de esta. Reconoce en ello una tendencia de época y ve una larvada pero cada vez más abierta necesidad de las mujeres de sacar a luz la fuerza de su yo interior:

Nora ha entrado en conciencia de una individualidad que exige la libertad de vivir una vida nueva, lejos de aquel hombre, de aquel extraño a su verdadero ser [...] Ibsen [...] insinúa que en determinados casos y para los tipos más avanzados de la especie, el alma tiene un derecho que prima por encima de los derechos sociales, ya que a los nuevos grados de conciencia corresponden deberes también nuevos y más grandes que redimen los otros (Iris, 1910: 233).

Ante la conciencia íntima que impulsa a forjar una nueva vida libre (¿emancipada?) de fuerza universal, "no hay patria ni familia, ni credo» a los cuales sujetarse, ya que los derechos del alma los superan. Patria, familia y credo son puestos en entredicho por Echeverría, una mujer aristócrata, filiada con héroes patrios constructores de la nación, que mantiene relaciones con la Iglesia Católica, casada y madre de cuatro hijas...

Su adscripción a la teosofía, cuya filosofía subyace en sus interpretaciones críticas, la hace privilegiar lo espiritual sobre lo mundano y material, los deberes para con el desarrollo personal íntimo por sobre los sociales, la hermandad con los que profesan su ideario como filiación más verdadera que los lazos familiares. Para ella, la escritura que hace circular en el espacio cívico-público es parte de su vocación y misión autoimpuesta de despertar conciencias, de derrumbar muros de contención, de hacer aflorar esos «yo» internos superiores que se ocultan tras la máscara social. Y esto es posible sólo si ella misma recorre ese camino, en y a través de la escritura:

He sufrido dos partos: el de mi criatura ${ }^{30}$ y el de mi subconsciente, al fin exteriorizado, que halló cauce en el mundo. [...] He franqueado la portada de un mundo nuevo. [...] Precisaba que arrojase todas estas falsas vestiduras. Me embarco para hacer la más interesante travesía. Voy al encuentro de mí misma. Tengo el derecho a ser «yo» [...] para dirigir mis pasos donde yo quiera (Echeverría, 2005: 249).

Iris tiene conciencia de estar rompiendo anquilosadas estructuras desde su vulnerabilidad femenina, en un mundo no acostumbrado a que las mujeres intervengan con firme-

\footnotetext{
30 Se refiere al de su cuarta hija, Iris, que coincidió con la publicación de su primer libro anónimo en 1904 (Hacia el Oriente) y con la elección de su seudónimo: Iris.
} 
za y espíritu contestatario en la palestra pública. Anticipa el escándalo que sus opiniones liberales provocan, las que defienden su derecho moral a ser consecuente con su nueva visión de lo humano y de la cultura, voz extremadamente solitaria. ${ }^{31}$

Si el poeta noruego provocó una revolución con su pieza, yo también afronto las iras que se desencadenen con mi artículo, creyéndome pagada de sobra si me comprenden aquellos que alguna vez han sentido palpitar en el fondo de sí mismos un «yo» más profundo y más grande que el que circula con determinado nombre en el mundo! (Iris, 1910: 218).

Quizás su agenciamiento más cercano lo tenía con ciertas mujeres literatas que cultivaban un «espiritualismo de vanguardia» (Subercaseaux, 2001:12), el cual era heterogéneo en su interior y, a diferencia del feminismo europeo y estadounidense, en esta etapa (primera década del siglo, hasta 1918) no incluyó reivindicaciones políticas: ni lucha por el voto femenino ni por derechos cívicos. ${ }^{32}$ Sí entendía Iris que sus reivindicaciones en las definiciones y prácticas de género, que buscaban ampliar y cambiar el espacio de lo femenino, eran en sí una lucha revolucionaria y por tanto, política, ya que incidían en la transformación de la totalidad de la estructura social, para ella, revolución tanto o más grande que la de la Independencia, que no dio libertad ni igualdad a la mujer. ${ }^{33}$

\title{
ALTERIDAD/SUBALTERNIDAD DE LO NACIONAL VS LO EUROPEO: CUESTIÓN DE RAZA Y DE REFINAMIENTO
}

\author{
MUSA CHILENA - A MARÍA GUERRERO \\ Peregrina incansable, que cruzando \\ de un pueblo al otro vas, de zona en zona \\ el genio de una raza te acompaña.
}

F. A. Concha y Castillo, Consejo de Instrucción Pública, Universidad de Chile

Iris, en su afán de ser una «mujer nueva» sin poder serlo enteramente, luchó contra las huellas impresas en su cuerpo y espíritu por su formación dual: española tradicional (por parte de padre) y francesa ilustrada (por parte de madre); estaba así escindida por dos matrices de las elites locales: del petit monde chileno-santiaguino tradicional y del cos-

\footnotetext{
${ }^{31}$ Sólo una década después se articulará orgánicamente con algunas socias del Círculo de Lectura de Señoras (1915) y del Club de Señoras (1916-1925). Nunca se relacionó con mujeres chilenas de clase media y obrera que editaban periódicos y boletines anarquistas, cuyas críticas a las estructuras sociales y patriarcales eran rotundas, ácidas, absolutas (Palomera y Pinto, 2006).

32 Más aun, se declaraban contrarias, avaladas en su visión dual de lo femenino/masculino; para ellas, las mujeres se desenvolvían en lo espiritual, lo refinado, lo culto, en las delicadezas humanas; los hombres, en cambio, en el para ellas brutal ámbito del poder político, del dinero, del manejo del Estado, de la industria. No quieren estas mujeres contaminarse ni degradarse al entrar a ese mundo: se lo dejan al hombre, o a lo más, intervienen en él a través de ellos en defensa de sus propios valores (contra el ateísmo o el socialismo).

33 «Para cada nuevo derecho que la humanidad ha necesitado ejercer, ha sido menester una revolución. [....] Cábenos la honra de ser nosotras las primeras mujeres que abrimos la puerta de la vieja jaula colonial» (Echeverría, 2001: 225).
} 
mopolita moderno. Estas vinculaciones explosionan en ella tras vivir una posición más igualitaria en Europa (1899-1902), que la hacen resentir a su regreso ser mujer en una sociedad periférica con hegemonía masculina y distanciada del arte y la cultura centrales. Por esa contradictoria raigambre, siente necesidad de levantar una voz propia, en una búsqueda escurridiza que la desterritorializa una y otra vez, manteniendo una dialéctica entre la dominancia y la sub-alternidad, entre su raigambre con lo chileno y lo europeo.

Un factor que recurre en el imaginario de Iris es la cuestión de la evolución de lo humano vinculado a la raza, adscribiendo a posiciones neo-darwinistas dominantes en esa Época del Imperio (Hobsbawm, 1998). Circulan discursos como el siguiente de El Mercurio (s/a. (1910): «El florecimiento literario se está produciendo por el desarrollo natural de la inteligencia de la raza y como satisfacción de sus necesidades espirituales», o, como expresa nuestro epígrafe publicado en El Diario Ilustrado (1908): el genio de la Guerrero está contenido en su raza, asimilada por la chilena mediante el título "Musa Chilena».

Los análisis culturales y sociales suelen vincularse a lo racial y a la equivalencia biología-cultura, ${ }^{34}$ enclavando pasiones, temperamentos, vicios, límites y potencialidades del ser en su organismo. Estos factores serían incidentes en la producción y la receptividad artístico-cultural, lo que se impondrían desde el fondo de la psiquis y de la tonalidad corporal.

Esta «inteligencia de la raza» alude a la elite de los espíritus evolucionados, los que suelen coincidir con las clases que han cultivado por generaciones la densidad del pensamiento y la finura de la sociabilidad. Este supuesto focaliza a un reducido sector nacional, a aquel capaz de dialogar en igualdad de inteligencia, comprensión y apreciación con las producciones provenientes de los seres más desarrollados del planeta: los europeos. Pero no todos ellos: para Iris, «la voz de la raza» chilena, por considerarla prioritariamente española (por cierto, olvida las raigambres indígenas) permitiría que sólo unos cuantos puedan entender y disfrutar con empatía total los dramas «modernos»: serían aquellos criollos que se han aculturado en lo francés:

El ladrón de Berstein fue una velada exquisita para esa parte del público santiaguino, sin duda la más pequeña, que lee, piensa, come y viste en francés. [...] El refinamiento de la civilización ha hecho a ese pueblo [francés] capaz, más que ningún otro, de responder a las múltiples vibraciones de la vida universal (Iris, 1910: 105-7).

Iris es representante privilegiada de ese público que vive «en francés», capaz de captar en toda su exquisitez un espectáculo de autoría francesa (aunque representado por una compañía española: la de María Guerrero). Un caso extremo de esta fisura visualizada por Iris entre el "gran público» y los que «hablan en mi idioma» es cuando propuso a la compañía española Tallaví que escenificara para ella y sus amigos La intrusa, de Maeterlinck, en una función "en familia», con todos los elementos y exigencias de una puesta en escena profesional. Esto, reeditando la más pura tradición cortesana. ${ }^{35}$

\footnotetext{
34 Recordemos la influencia del ensayo Raza chilena de Nicolás Palacios, publicado en 1904.

35 En esta época, los palacios de la oligarquía santiaguina solían tener salas de teatro, donde representaban dramas realizados por ellos mismos como también, invitaban a artistas europeos que se presentaban en el Municipal a realizar allí funciones privadas. Este fenómeno se repetía en las principales capitales del mundo.
} 
Deseaba mucho conocer la interpretación que el Sr. Tallaví podría hacer del teatro de Maeterlinck. [...] se resolvió a dar una función en familia [porque] para ser comprendido, Maeterlinck necesita de cierto grado de desarrollo psíquico en los seres. [...] Los que viven ya con ese sentido viejo o nuevo, pero en todo caso más sutil, que les permite percibir lo oculto, son los únicos seres para quienes es accesible la obra de este autor (Iris, 1910: 48).

Esta auto-percepción de extrema sensibilidad espiritual en ella y en sus próximos encuentra su reverso en un contradictorio espíritu neo-colonial. Iris posee una soterrada conciencia de ser parte de lo subalterno, de lo «otro» respecto del centro. En un espacio chileno sin producción profesional propia en el terreno del espectáculo, la dependencia se percibe como postergación y atraso. La vida, la cultura, la vanguardia parecieran estar en otra parte. Consumidores de los resabios, se celebra y se aspira a que lo que llega al país sea realmente lo más valioso y moderno del centro: de ahí las constantes loas a los más afamados intérpretes europeos que llegan al país. Aunque ello termine en un verse en el espejo de la mirada del otro como un subalterno, cuando se aspiraba a establecer una equivalencia.

Echeverría lo experimentó en la sede del Club de Señoras en 1917, dio una conferencia íntegramente en francés sobre la performance de la actriz francesa Suzane Desprès, quien venía con el destacado hombre de teatro Lugne Poé. ${ }^{36}$ Recordó la crítica los triunfos de la actriz en París, presenciados por ella allá, y lamentó ver «alejarse a la estrella que arrojara la luz prodigiosa de su talento sobre los sedientos habitantes de esta tierra, tan alejada del manantial de donde fluye el genial talento francés!» (s/a. (1917) Editorial. Revista Familia).

Entonces, identidad con lo francés pero también desgarro por su marginalidad respecto a la vivencia continua y directa, cuerpo a cuerpo, con esa experiencia artísticocultural, calificada por una cadena de elegíacos adjetivos: estrella, luz, prodigio, talento, manantial, genio y nuevamente talento. La identidad no recíproca francesa/chilena afloró en la inesperada visión de exotismo indígena que aquellos pretendidos hermanos franceses tuvieron, desde su postura colonialista, en relación a la chilena:

El Club de Señoras festejó a los nobles huéspedes que se manifestaron sorprendidos de la cultura de nuestras damas... Abro aquí un paréntesis para añadir, a fuer de chilena, que ya era tiempo -y sobrado!- para que los europeos no se admiren — y en nuestras barbas! — de esa cultura que, al leer en sus rostros la sorpresa que les causa y al oír proclamarla con ingenua sencillez, nos prueban que esperaban vernos vestidas con plumas lo que jes claro! les habría sido más agradable (s/a. (1917) Editorial. Revista Familia).

Esta lectura desde el prisma del colonizado, que reconoce contradictorias matrices culturales, activó la polémica vigente desde la Independencia en su tránsito de lo español a lo francés ilustrado. En ese siglo XIX cientificista, en el cual desde su segunda mitad rige la idea del determinismo biológico-cultural, ora se exalta el heroísmo y reciedumbre de la herencia española o se la desprecia por tradicional y sobrepasada por la historia. La antigua oposición opresión-libertad, dominio-emancipación, oscurantismo-ilustración se rearticula en la oposición ibérico-latino, y dentro de esta, lo francés ya no sólo como luz científica y democrática sino como refinamiento espiritual, modernista y decadente.

36 Lugne Poe es el director de la primera versión de Ubú Rey de Jarry, en 1896, por el Théatre de l'Oeuvre. 
Así, Iris y otros críticos, junto con negar lo grueso de lo español, se identifican con sus representantes excelsos: la actriz María Guerrero se transformó en epítome de esa grandeza celebrada como propia por la raigambre común, destacando en especial cuando ella actúa la tradición: el clásico del siglo de oro español. ${ }^{37} \mathrm{Y}$ le conceden aun otro galardón, al reconocer que fue capaz de interpretar adecuadamente, sin traicionar, el moderno y refinado espíritu francés del teatro de Berstein en El ladrón:

Entre los espectadores de esa noche de teatro se dudaba de que el alma española, heroica y grande, impetuosa y pasional, se adaptase a las creaciones de un teatro como el francés, que es trasunto de un modo de ser más complejo, movible y misterioso (Iris, 1910:107).

Según Iris, «aunque lo natural es que se refleje el producto de la propia raza», los esposos Guerrero-Díaz de Mendoza dieron:

una pieza interpretada con toda la finura de matices, en toda la complejidad tumultuosa y pasional que requiere la obra de Berstein. Aun como «mise en scene» la pieza tuvo todo el refinamiento y precisión de detalles con que se presentan las obras en París, bajo la dirección de los propios autores (Iris, 1910: 107).

Desliza ella en la crítica que conoce de primera mano cómo se presentan las obras en París, y por tanto, se califica a sí misma como opinión autorizada en la materia.

Esta ligazón con lo español se desmorona ante las obras de espíritu «moderno», valoradas por su sutil realismo psicológico, y ante las simbolistas. Allí el choque es frontal y se reaviva el soterrado espíritu de combate y desarraigo con lo colonial español. El juicio de Iris es radical: les propone a los actores españoles que renieguen de los autores de su nación para adherir a los franceses, austríacos o nórdicos, que expresarían esta sensibilidad más avanzada y quienes elaboran una palabra poética de tal expresividad sensitiva que en ella el idioma español sí alcanza profundidades desconocidas. Sería el caso de Tallaví tras su «función privada» de Maeterlinck:

El señor Tallaví se había encargado de probarme que las palabras tienen «color» y me lo probó y me convenció de tal manera, que a las suyas les regalo "par dessus le marche», peso, forma y volumen. Sus palabras son redondas, son puntiagudas, describen círculos, y caen muy pesadas en el alma.

Si contra toda mi costumbre y haciendo una excepción rarísima me permito darle un consejo, yo le diría que diese un adiós eterno a don José Echegaray, las buenas noches por lo menos a don Benito Pérez Galdós y entrase triunfante como en tierra conquistada en el teatro de Maeterlinck, para el que no sólo es un Llamado por la naturaleza sino un Escogido por la vida (Iris, 1910; 64).

\footnotetext{
«En nada está María Guerrero más perfecta, más digna de la admiración de los entendidos, que en las obras clásicas. Las mujeres de aquella época parecen haber reencarnado en ella. Es tan profundamente española la ilustre intérprete que su talento aparece con líneas más fuertes y seguras cuando tiene que mostrar la esencia de la grande alma española de los siglos de oro. [ella] saca del fondo de la tradición española, con acentos castizos y modernos a la vez, una gran voz en que habla la raza» (s/a. (1910). Teatro Municipal: El desdén con el desdén. Diario El Mercurio, 29 de octubre). Equivocadamente, incluyen a Moreto dentro del Siglo de Oro, siendo neo-clásico.
} 
Las autorías son puestas por Iris en jerarquías de menos a más: el teatro centroeuropeo y nórdico son la medida de lo más avanzado y el teatro español de lo más anticuado. El teatro francés sería el más capaz de cumplir con lo esperado en el arte en la modernidad: seguir el movimiento de la vida contemporánea.

sólo la producción dramática francesa sigue el movimiento contemporáneo y por eso posee el indiscutible privilegio de arrebatarnos, produciéndonos en cada una de sus creaciones esa emoción vívida que no necesita esfuerzos para apoderarse de nosotros, porque es el simple reflejo de nuestra propia sensibilidad (Iris, 1910: 91).

La concepción del teatro francés como «simple reflejo de la propia sensibilidad» propone, para Iris y su circuito afín, una reciprocidad total, una no distancia, un juego de espejos no distorsionado en que cada plano reflejado conserva su contorno transparente, aun cuando la teoría post-colonial se encarga de advertir sobre la mirada de des-conocimiento del metropolitano respecto a sus pretendidos e imposibles iguales: los colonizados (Memmi, 1983). Esa completa diafanidad percibida con lo francés se torna en discontinuidad enervante con la dramaturgia (y la cultura) españolas, sentida como exacerbación ampulosa de las pasiones y debilidades humanas, de lo caído frente a lo puro, "con sus situaciones extremadas y casi siempre falsas, con sus caracteres demasiado exagerados» (Iris, 1910: 91). Oposición binaria de la experiencia que la llevan a un descalce en relación a una de sus vertientes étnicas propias: la española.

Esta sensación de identidad plena con lo francés, esta pregunta identitaria que crea sentimientos ambivalentes con su ser chileno, en ocasiones lleva a Iris a rechazar dicha ascendencia nativa que perturba la comentada simetría absoluta. Como Luis Oyarzún, quien en su Diario íntimo elabora la alegoría de ser chileno como «saberse de esta tierra, ansiando la otra tierra (Europa), conflicto y comunión, comuniones en conflicto». O, como en Rayuela de Cortázar, ser «Del lado de allá», «Del lado de acá» y «De otros lados» (Hozven, 2001: 215).

\title{
DRAMATURGIAS Y ESCENIFICACIONES EUROPEAS: CUESTIÓN DE VERDAD E IDENTIDADES MODERNAS
}

\author{
Si entendemos el arte del comediante como una \\ energía primaria del alma humana, que en su \\ proceso vital asimila la literatura y la realidad [...] \\ la interpretación de este arte desemboca en la gran \\ corriente de la comprensión moderna del mundo.
}

Georg Simmel, El comediante y la realidad

\section{El silencio en el teatro francés: vibraciones de una intimidad inconfesable}

Para Iris, el arte perfila la experiencia vital en su diversidad intelectual-emotivo-sensorial. Ella no busca la complacencia de un equilibrio pacificador; por el contrario, su vocación es la aventura intrasubjetiva de un arte que indague en los espacios ocultos, inconscientes, oscuros de sí como sujeto moderno. «El arte es revelación de una verdad 
que se oculta, de una belleza que se esconde [...] es la fugaz transparencia de un ideal inaccesible» (Iris, 1910: 39). Sería coincidente con la concepción del arte de Levinas: «La existencia en ocaso de la imagen estética - la imagen artística como <el verdadero evento de oscurecer, un descenso dentro de la noche, una invasión de la sombra» (citado en Bhabha, 1994: 15).

El ideal del teatro para esta crítica es que sea «el intérprete de la propia vida» enigmática y escurridiza. Ella se identifica con el teatro francés porque sus autores «hieren la imaginación de todos quienes encuentran en ellos los intérpretes de su vida profunda e inexplicable [...] sacudiéndonos con las vibraciones de nuestra intimidad inconfesable» (Iris, 1910: 192). ${ }^{38}$ Valora un teatro adscrito al "movimiento psíquico», que la lleve a indagar en sí misma y en su entorno, para percibir hasta al niño en el seno de su madre, al decir de Ibsen: es el momento de hacer aflorar lo oculto, los terrores, las mentiras, cuestionar un «deber ser» y reconocer aquello en lo que está deviniendo «la nueva mujer».

La crítica, mediante la exploración de su propia intimidad, realiza confesiones íntimas alejadas de lo esperado en una "modesta» mujer casada, a propósito de la dura y hasta cruel obra de Henri Bataille, La marcha nupcial: «Esa constatación [de lo inconfesable] destruye todos nuestros ensueños, desquicia nuestras creencias... La infidelidad nos aterra, pero se nos impone» (Iris, 1910: 197). Y agrega, desde la sabiduría de una mujer experimentada: «Para ser fiel hasta la muerte es menester que la muerte no tarde demasiado» (Iris, 1910: 199).

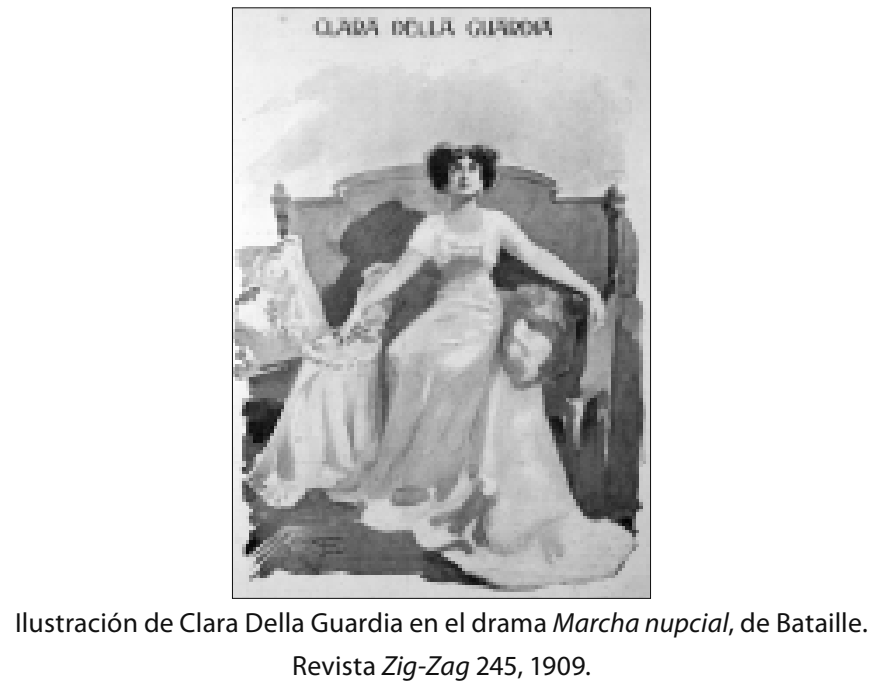

Para Iris, hay dos autores cuya creación son el epítome de esta nueva forma dramática, paradojalmente, ningún francés sino un belga y un noruego:

Este desarrollo espiritualista moderno ha encontrado en Maeterlinck y en Ibsen sus intérpretes fieles. Ellos se han puesto a la cabeza del movimiento psíquico, que pide a la escena

38 Este concepto de Iris evoca la concepción de Arthur Miller (1988: 133) en cuanto a que su exploración dramática en lo social lo involucra desde su más oculta intimidad; declara: «mis mejores escritos son aquellos que me hacen sonrojar». 
teatral un trasunto de su vida íntima, un reflejo de sus luchas obscuras, de sus silencios profundos, de sus triunfos o de sus derrotas mudas. En esto, como en todo, el arte es el precursor de la vida [...] Maeterlinck es el heraldo del progreso del alma (Iris, 1910: 50-1 y 57).

Adhiere a un teatro de veladuras, de lo insinuado e intuido, por considerarlo equivalente a la cultura de su tiempo, que oculta a la mirada de otros lo que verdaderamente ocurre en el fondo de cada ser y atempera la expresión de las emociones en público para manifestar un civilizado control de sí. Por ello, esta teórica del teatro afirma, a propósito de La intrusa de Maeterlinck, que el teatro moderno necesita replantear la tragedia clásica:

El teatro moderno no necesita, como el teatro griego [...] que en el arranque supremo de la desesperación, Edipo se despedace los ojos y nos exhiba sus órbitas sangrientas para sentir el frío de la desolación, el horror del desquiciamiento... Basta que un abuelo ciego y decrépito, en el fondo de una pobre alcoba, nos hable en la sencillez del estilo familiar, a la mitad de una noche cualquiera de la vida para que sintamos, con más hondura que entonces, el hielo del último abandono, el miedo al gran desconocido que nos acecha tras la puerta (Iris, 110: 57).

Esta capacidad profética que Iris le concede al arte dramático moderno no se propalaría en grandes anfiteatros ni se reforzaría en voces de coros multitudinarios, ni se realizaría en el accionar del cuerpo torturado del actor. El desplazamiento se produciría desde la polis, la arena pública que exhibe la caída del héroe para recuperarlo colectivamente tras la catarsis que castiga/redime su transgresión fatal, hasta el terreno callado de la subjetividad moderna que "corresponde sin duda a muchos grados de afinamiento en la raza», la cual no por menos exhibida es menos sentida:

El sentimentalismo moderno se ha refugiado adentro, muy adentro de nosotros mismos y ahonda más mientras menos se exterioriza, ganando en verdad íntima tanto cuanto pierde en apariencias externas. [...] Los nudos de afecto que se atan o que se desatan en el silencio, o en la sombra de nuestra intimidad profunda, tienen más repercusiones secretas que los que se manifiestan en el escenario social. (Iris, 1910: 93-4)

Este teatro, según Iris, reconfigura su estructura expresiva; desde este otro fin de siglo, esa mirada coincide con algunos elementos reivindicados por el teatro postmoderno (Pavis, 2001). El elemento central para Iris sería el quiebre entre acción-representación: ya no se trata de la «imitación de las acciones», como lo define La Poética:

En el teatro del inspirado místico belga no hay declamación, no hay suceso; todo se siente, se adivina o se vive interiormente. No se le pide ningún recurso al brillo de la palabra, a la elocuencia del gesto o a la violencia de la actitud (Iris, 1910: 48).

Su armazón es el silencio, el intervalo, la fisura, el quiebre del lenguaje. La palabra no es referencial a la acción que imita; es palabra sugerente, indirecta, insinuante de lo que no está allí, de lo que está impedido de manifestarse, pero que vuelve en el eterno retorno de lo reprimido. Es necesario, a la manera reconocida por Freud, el desplazamiento, la figura jeroglífica, el rodeo para acceder a lo herméticamente clausurado por nuestro dolor... y por nuestro temor a él. 
Esas palabras dichas con lentitud, en intervalos prolongados de silencio, adquieren un inmenso valor, pues ganan en intensidad lo que pierden en exterioridad. [...] Esas palabras breves y opacas van empapadas de una emoción interior, van marcadas con el sello de la fatalidad antigua y nos conmueven más que las tiradas grandiosas de Echegaray, más que todos los discursos brillantes (Iris, 1910: 49 y 53).

Este lugar inaccesible a la palabra, que ya no es el depósito del conocimiento sobre lo humano sino que muestra desolada su incapacidad para expresar la subjetividad del sujeto contemporáneo, es lo que, para Iris, el teatro puede revelar a través de la teatralidad: del cuerpo, ya no como mimesis de lo que la palabra del poeta dibuja sino como aquello que el cuerpo del actor revela desde sí mismo. En especial, el cuerpo femenino: «Clara Della Guardia expresó con dolorosa intensidad esos tonos de alma que no tienen cabida en el lenguaje y que son la muda contracción de lo débil oprimido por lo fuerte, de lo pasajero por lo eterno!» (Iris, 1910: 146).

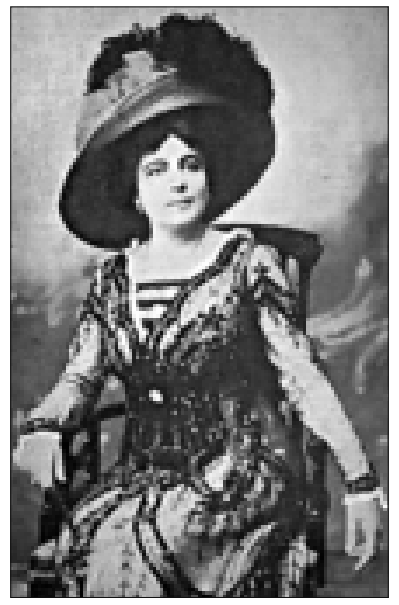

Clara Della Guardia (1909). Revista Zig-Zag 243.

El cuerpo convertido en puro gesto se vincula a lo arquetípico: el dolor ha modelado por siglos las actitudes reveladoras de éste; el repertorio iconográfico clásico subyace a esas formas que adopta el cuerpo para manifestar esas emociones modernas, pero al mismo tiempo arcaicas, acorde con los planteamientos del simbolismo. El más hondamente dramático sería el drama escénico con menos movimiento pero con mayor estasis. El más emotivo, el irradiado desde el fondo de la mirada, cuyo movimiento hacia el interior, sin la consecuencialidad horizontal de la palabra, rompería el tiempo y el espacio, segmentando al espectador de su vivencia del tiempo presente. Así lo percibe Iris en la performance de Clara Della Guardia cuando, interpretando a Nora en Casa de muñecas, adopta la resolución dramática crucial de romper con todo lo conocido y aceptado, y adentrarse en una vida nueva, lejos del hogar:

Ella logró no sé cómo — ese es su prodigio- asomarnos a la vida trascendental que todos presentimos, aunque no la hayamos vivido... Sus ojos dilatados, ahondados, fulgurantes, dejaron pasar el infinito... donde todo cambia de nombre, donde cesan el espacio y el tiempo, donde la vida se prolonga hacia delante y hacia atrás en vertiginosas proporciones [...] avanzó como sonámbula [...] mientras sus ojos obscuros se hundían en monstruosa perspectiva... Nos estremecimos ante aquella mirada de mujer que nos sumergió [...] donde 
se realizan nuestros presentimientos y donde la palabra «imposible» pierde para siempre su significado... No dijo una palabra, pero Ibsen asomó a los ojos de la mujer la vida sin nombre (Iris, 1910, 231-2).

Ese «no dijo una palabra» es revelador de que hay una «vida sin nombre»: innombrable. Tampoco Iris tiene palabras para expresar este tipo de experiencia estética, ya que satura su párrafo de puntos suspensivos, dejando el hueco de lo no dicho por no poder decirlo. Sí quiere dejar constancia de la expresividad del rostro, del cuerpo, de la transparencia espíritu-sentimiento-pensamiento: en ellos logra espejar en semisombra lo situado en el fondo de una gruta, no accesible a signos convencionales como la palabra. La corporalidad es postulada por esta estética como una fuente de sentido en el teatro casi o tanto más fuerte que la palabra: un cuerpo atravesado por una situación trágica, por una emoción, un sentimiento o un estado espiritual es apreciado por su acceso a la comprensión de lo humano oculto.

Como ocurre en la vida real, este cuerpo gestual porta su carga: no por casualidad floreció durante el siglo XIX la llamada "ciencia de la fisiognomía», ${ }^{39}$ que prometía descifrar formas corporales, gestos, coloraciones faciales como manifestaciones de emociones y moralidad. El ojo, principal órgano del conocimiento moderno, fue adiestrado para tales develamientos, en una "gastronomía del ojo» ejercitada por la burguesía en la ciudad moderna (Balzac, citado en Sennett, 2002: 357). Iris bien lo sabía:

Pero, ¿la vista? Eso es otra cosa [que el oído]. La palabra se adapta a la conveniencia, pero lo que revela el gesto, el ademán, la leve contracción del rostro, lo que muestra el súbito encarnado de una mejilla, ¡eso es la vida misma! (Echeverría, 2001: 86).

Frente a la «verdad» de la gestualidad corporal, la palabra queda cuestionada. En el gesto se plasmaría el recorrido de la mente/psiquis y es ese desciframiento de experta en la semiosis del cuerpo lo que Iris aporta como crítica teatral a su público lector. Así lo establece en relación a la construcción actoral de Hamlet por Tallaví:

El príncipe lee en actitud descuidada con la pierna posada sobre el brazo de la silla. Los ojos del actor recorren el libro y su fisonomía móvil, profunda, de tan extraña plasticidad, deja leer a su público lo que el libro le dice a él... y por supuesto que su fisonomía es de mayor elocuencia que los conceptos contenidos en las páginas... El viejo cortesano... le pregunta ¿Qué leéis señor? y él responde: «Palabras... palabras... y palabras!», haciéndonos sentir en la diversa y rica inflexión que presta a esas tres voces todo lo que la palabra tiene de deleznable y de frágil (Iris, 1910: 35).

La adhesión que Iris tiene por el drama y la tragedia modernos la hace extensible a su entorno cultural chileno/latinoamericano e hispánico, en ese "nosotros» que enuncia en relación a la necesidad de pensarse como cuerpo del dolor. En este punto axial, por ejemplo, ante una obra de D’Annunzio, Iris ya no se siente latina ni francesa ni italiana sino española-cristiana. Su raigambre española-católica emerge ante su vivencia ritual del sacrificio, de la flagelación, del dolor, de la renuncia... y de la redención por el dolor.

39 Es interesante acotar que una apreciada conferencia solicitada a un experto por el Club de Señoras en la que participaba Iris hacia 1922 fue acerca de la fisiognomía y su capacidad de develar las emociones humanas. 
En medio de la admiración que le profeso encuentro un punto de absoluta discrepancia. Él cree sólo en la fecundidad del Placer y yo sigo creyendo en la absoluta eficacia del Dolor. [...] Su alma pagana, serena y riquísima, no lleva impreso el sangriento estigma de veinte siglos de cristianismo, cuya herencia tenemos nosotros (Iris, 1910: 165).

El «espiritualismo de vanguardia» que orienta la práctica escritural de Iris la aleja de las vertientes nihilistas finiseculares que abjuran de lo trascendente y cuestionan las bases de la moralidad occidental: ese eclecticismo moral, «que se traduce en secularización sin fronteras de los valores», con su «fuerza subversiva incalculable» (Picó, 1992: 13), no es el modernismo al que ella adhiere, puesto que reconoce órdenes referenciales a su cultura (extensibles a la chilena) inscritos en lo cristiano y greco-latino, incorporando a Oriente dentro de lo cristiano. La cita reciente lo confirma, y su concepto de orden, realidad, moralidad, repugna de lo burgués positivista y pragmático, proponiendo descalces, nuevas miradas y prácticas, diferente valoración de las instituciones y de la construcción de los géneros en lo privado y lo público.

Interpreto más bien que Iris, conciente del paulatino proceso de desintegración del mundo tradicional en la Europa centroeuropea y nórdica, resiente la lentitud del proceso de modernización en su ámbito local (descalce con lo centroeuropeo) y quisiera con su escritura crítica acelerar los cambios. Ello, a partir de descifrar y deconstruir el sentido posible de esas obras dramáticas y escenificaciones europeas presentadas en Chile, las que, más que indicar un "modo nuevo de ver la vida moderna» (el cual se remitiría al plano del discurso) le interesa propulsar los modos «de experimentar una realidad social nueva» (Picó, 1992: 18-9). Porque su exégesis apunta en definitiva a una praxis: a un modo de actuar del sujeto, encarnadamente, en lo social. De aquí que Iris desestima las dramaturgias hiperbólicas, clásicas y románticas, y concuerda con que en la modernidad las pequeñas cosas, los detalles, las vidas mínimas, son capaces, mejor que los esfuerzos totalizantes y grandilocuentes, de dar cuenta de las dinámicas subterráneas de esa modernidad inconstante, en tránsito, rotas sus coordenadas lineales de espacio/tiempo. Enhebrar, esbozar una trama en que los microcosmos pueden conectarse a la realidad, en que los fenómenos interactúen y se asocien, vinculados a los estados emocionales y psicológicos, es el proyecto de Iris (gran seguidora de Bergson), como lo fue también el de Simmel (Picó, 1992: 22-3).

\section{La expresión de la «verdad» psíquica-corporal: el naturalismo «científico»}

Si el realismo psicológico francés fue una estilización del realismo neo-romántico y si el simbolismo de Maeterlinck era una reacción en contra del materialismo positivista, otra nueva corriente estética sí era deudora de este positivismo: el naturalismo "científico». Este es el reino de la verdad observada al detalle, como ante un lente de aumento: todo, lo más íntimo y lo más corporal, lo objetual, queda a la vista, exhibido ostensiblemente. Iris, aunque declara preferencia por las dos primeras vertientes, se pliega con entusiasmo a esta estética sólo si la considera realizada a cabalidad, es decir siempre que logre despertar lo que ella busca en el teatro: la conmoción espiritual y moral, sufrir una experiencia de transformación profunda y de comprensión de la realidad y de lo humano. Esto, mediado por la posibilidad de gozar el arte de la representación propiamente tal, en un lenguaje que posea «verdad» performativa.

En este tiempo epigonal de la «ilusión teatral», que pone una cuarta pared frente al público y produce un ambiente realista en el escenario, donde todos los elementos del 
diseño teatral y las actuaciones concurren a un concepto de «verdad» que imita o encarna lo real (Zsondi, 1994), los naturalistas exacerban dicho concepto mediante la «verdad científica» de la escena, de la cual Antoine ${ }^{40}$ fue su máximo exponente. Priorizan la creación del «ambiente» a través del diseño: escenografía, vestuario, utilería, relación del actor con esos elementos y entre sí, ${ }^{41}$ en tanto la actuación se embebe de tal ambiente y desarrolla una producción gestual característica que amalgama condición social, etaria, emocional, psicológica, físico-biológica. El creador teatral se convierte en un estudioso de ambientes y caracteres, confluyendo en ello todas las fuerzas en el actor.

El drama moderno, por actualizar los eventos desde la narración y no desde la acción dialogada, se enfrenta al desafío de recorrer la transformación interna y externa del personaje y de la situación, conservando en ese transcurso el valor de «verdad». La plasticidad se pone al centro de la construcción del verosímil teatral, fundamentalmente en el terreno de la actuación, la que descuella ya no en los dramas refinados franceses sino en los poderosos y desgarradores españoles. Dice Iris a propósito de El místico, de Rusignol, interpretado por Tallaví:

Aparece el sacerdote cadavérico. ${ }^{42}$ Es imposible llevar más lejos la perfección del arte plástico. [...] La plasticidad del señor Tallaví es única para dar a su cuerpo y a su rostro el aspecto de la verdad. Se enflaquece, se demacra, se consume. [...] Tallaví interpreta no ya sólo con verdad humana y perfección artística sino también con escrupulosidad científica. La enfermedad que aqueja a sus personajes toma todo el cuadro sintomático de que va acompañado (Iris: 1910: 20-1-2).

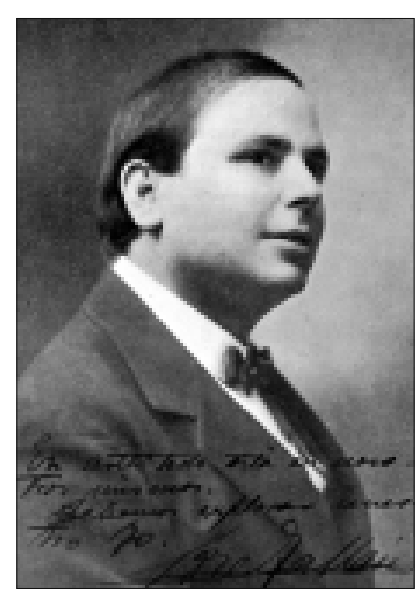

José Tallaví. Revista Selecta 5, 1909

\footnotetext{
Su ideario y obra era conocido en Chile a través de la prensa y la crítica especializada.

41 Al comentar la puesta en escena de Doña María la Brava, se conceptualiza lo anterior como una «escrupulosa y científica propiedad»: «Pero todo esto se entiende y se siente cuando la obra está vestida con escrupulosa y científica propiedad, cuando los muebles, los utensilios, las armas, el decorado, todo evoca el perfume de una época extraordinaria» (s/a. (1910). Doña María La Brava. Diario El Mercurio, 24 de octubre.

42 El que fuera en la primera escena un joven mozo.
} 


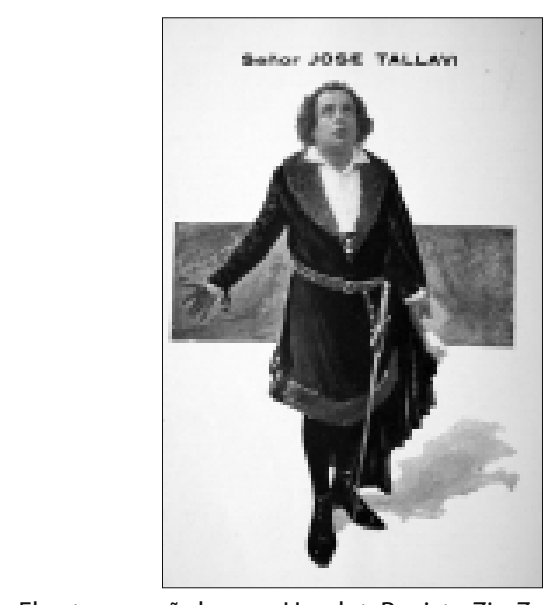

El actor español como Hamlet. Revista Zig-Zag 228, 1909.

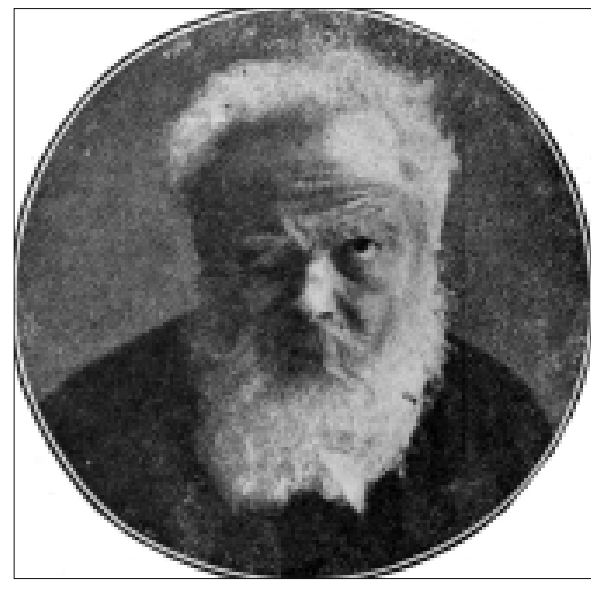

José Tallaví en El místico. Zig-Zag 228, 1909.

La dominancia de «enunciados de verdad» con autoridad médica y/o científica acerca del cuerpo (Foucault, 1992) en este tiempo seguía dando crédito al neo-darwinismo en términos de raza y género, como también, a la fisiognomía en su pretendida capacidad de identificar, desde las señales y formas del cuerpo, los temperamentos y la moral de las personas. Iris, como la mayoría de los ilustrados de su tiempo, no discutía sino adhería a estos preceptos. La jerarquización raza-género se proyectaba en términos socioeconómicos, laborales y geográficos (rural/urbano):

Los estados morales tienen todas las exterioridades que los traducen. Nos presenta los refinamientos de las personas de gran mundo en un juego elegante, sobrio y sencillo, nos muestra la rusticidad de los tipos populares, en hombres de ojos brutales, encendidos de codicia, en manos rudas, en espaldas torpes, y las degeneraciones humanas nos las exhibe con degradante y cruel realismo (Iris, 1910: 3). 
Iris no trepidaba en emplear estos «discursos de verdad» como recurso explicativo de las obras naturalistas, explicitando su código constitutivo sin someterlo a crítica. Si adhiere a un «espiritualismo de vanguardia» y a la teosofía, ¿cómo se compadece con ello? La teosofía de algún modo apoya esta perspectiva, ya que postula que el ser humano está en diferentes estados evolutivos, desde los más básicos a lo más avanzados (identificando con frecuencia el «progreso espiritual» con el «progreso de la raza», como en la cita anterior) y su tarea en la tierra es perfeccionar su estado; al no lograrlo en un trayecto de vida, la reencarnación le permite proseguir su desarrollo. Mas, en su eclecticismo religioso, la explicación cristiana lleva a Iris a rebelarse contra el determinismo biológico del cientificismo europeo como explicación de la conducta y el sentimiento, y su salida es rescatar la capacidad redentora de la gracia cristiana: ${ }^{43}$

Lo que yo creía sentimiento puro obedecía a la irracionalidad de los instintos arrasados ciega y fatalmente por la ley natural... cayó mi indignación y subió en muchos grados mi admiración de la necesaria redención cristiana y de la gracia consiguiente para vencer la naturaleza. [...] la gracia se nos da para quemar esos pésimos residuos [de la terrible ley atávica, de los pecados de los ancestros que nos trae la sangre... que son postulados al vicio] (Echeverría, 2005: 139).

Al estar remitido el ser humano a lo inscrito en el cuerpo desde épocas ancestrales, en el largo debate filosófico entre naturaleza y cultura, Iris opta por delegar a lo natural y a un ineludible inconsciente (¿colectivo?) lo que hoy la antropología y los estudios culturales remiten a la cultura, como por ejemplo, el valor del honor (femenino). Pero la naturaleza para Iris, como hemos dicho, es encarnación de estadios espirituales, razón por la cual la concibe trascendente a lo histórico y personal, irrumpiendo en las relaciones humanas con fuerza pasional; a quien vivencia este embate, le cabría la grandeza de sobreponerlo para avanzar en su perfección:

En esa fuerza de los conceptos de honor descubrimos una legitimidad natural que parece derivar su grandeza de un orden superior al humano y que nos conduce, dentro de esas ideas casi inconscientes, a la ley suprema que debe ser el fin primordial de la etapa de vida que vamos haciendo (Iris, 1910: 83). ${ }^{44}$

Debiendo el actor y la actriz en esta estética interpretar con «verdad» absoluta su situación físico/moral/psicológica, ¿a qué recurre para lograrlo? Es tal la impresión que provoca en el público y en la crítica este "transformismo» radical del actor desde su doblez preexpresivo a su expresividad actoral, que se reeditan polémicas encendidas que se arrastran desde Platón con Aristóteles, desde Diderot con D’Alambert. Hay elementos morales involucrados $^{45} \mathrm{y}$, en el caso de lo técnico-expresivo, la disyuntiva de Diderot es entre actuar

\footnotetext{
43 Se refiere a una conversación con un médico europeo, que le explica el escándalo de un padre que es sorprendido por su hija en el lecho con su propio esposo mediante razones biológicas puras, de instinto sexual que se canaliza en energías hacia lo hetero, homo o bisexual.

44 Crítica a Tallaví en Tierra baja, de Guimerá, 1909.

45 ¿El actor o la actriz ha de tener en sí los registros amplios requeridos en la representación de lo moral, siendo por tanto él un personaje con rasgos de mal, indignos en hombres de bien (Platón) o es un problema de organización de formas y estructuras de lenguaje, la imitación de la acción, al decir de Aristóteles?
} 
por control (fijar la actuación desde un esquema controlado por la mente) o actuar por emoción, al modo romántico (prima la intuición, el dejarse llevar por el estado emocional, en plena identificación actor-personaje). Iris denomina este doblez como «el hombre de la naturaleza» (pre-actoral) y el artista (en su doblez de personaje): "Tallaví es el mago de las transformaciones estupendas. Todos los artistas que he admirado en mi vida se superponen a sus roles, mientras que éste desaparece totalmente tras de su personaje». ${ }^{46}$

Iris apunta aquí a un aspecto central del debate crítico/técnico de la relación actorpersonaje, que también puede conceptualizarse como un «actor que ilustra neutralmente el texto» o que ocupa «medios artificiales, creando una estructura de efectos vocales y físicos» que crean una realidad extra-cotidiana de la representación, desde cuya fuerza se construye un imaginario acerca de lo humano» (Carlson, 1993: 455). Es éste también el candente debate de la crítica teatral en esta primera década del siglo XX en Chile. Según se valore una u otra forma de actuación, se postula una visión de lo teatral en relación al cuerpo de la expresión de lo dramático.

Iris establece un debate intertextual con otros críticos que destacan este mismo punto: en relación a la actuación de El místico, El Mercurio coincide con Iris:

Bien se ve que el gran actor Tallaví ha estudiado profundamente este personaje sin descuidar un detalle, hasta que ha llegado a reencarnarse en él. [...] Ya lo hemos dicho: Tallaví es el padre Ramón y el padre Ramón es Tallaví (s/a. (1910) marzo).

Para este crítico, habría un excedente histriónico en los códigos de artificiosidad naturalista empleados por Tallaví al que Iris no alude, una «crueldad» consigo y con el público, término que luego empleará Artaud para referirse al actor que indaga sin concesiones en su límite corporal: "Con los detalles minuciosísimos del proceso patológico, científicamente exactos, Tallaví es cruel con el público, le hace sentir una sensación extremadamente dolorosa». ${ }^{47}$

Crueldad artaudiana de un cuerpo orgánicamente atravesado e interferido por una marca física que exterioriza o es, en sí mismo, dolor. Iris, a diferencia del crítico de $E l$ Mercurio, considera que la manera de «morir» de Tallaví fue artísticamente adecuada: «Hemos visto morir sobre la escena con espeluznante realidad, hemos presenciado el avance de la asfixia, los supremos espasmos, la palidez mortal, la contorsión horrible y la cabeza que se dobla» (Iris, 1910: 22). Para ella, en una actitud moderna, a diferencia de lo que pudo esperarse en una "delicada sensibilidad femenina», ${ }^{48}$ era correcto y apreciable que el cuerpo del actor encarnara en detalle el momento de la muerte si lo hacía de modo exacto y científico.

En cuanto a la técnica actoral, los críticos chilenos, Iris incluida, prefieren la actuación por emoción que por control: El Mercurio enuncia esta apreciación, a partir de una

46 "La obra de arte no ha sido hecha para que brille el talento de un actor determinado sino para encarnar un tipo humano y de tal manera lo ha comprendido el genio del señor Tallaví, que después de tantas noches aún no hemos divisado al hombre verdadero, al hombre de la naturaleza que se oculta tras de cada artista» (Iris, 1910: 1-2).

47 «Tallaví fue ovacionado en los pasajes culminantes de su interpretación admirable, con un entusiasmo extraño, especialmente después de ssu muerte〉 que aplastaba a la sala con una impresión de cruel amargura» (S/A. (1910) Diario El Mercurio, 3 de marzo).

48 Recordemos que el médico Augusto Orrego Luco prohibía a su esposa Martina Barros asistir a las tragedias de la gran diva italiana Adelaida Ristori por temer a que la emoción que ella experimentaría como mujer dañara su embarazo. Él iba solo y la dejaba a ella en casa. 
obra naturalista muy exigente para el actor: Espectros, de Ibsen. Tallaví, en su propuesta de interpretación de lo humano en continuidad biológica determinista, perteneciente a un orden natural, realiza lo que fue calificada como una actuación escalofriante para un público que compartía esta premisa:

¿Cómo resiste Tallaví esos tres actos espantosos [...] graduando su enfermedad, aumentando los signos de su degeneración, aumentando el temblor de sus manos y piernas, el fulgor siniestro de sus ojos, los tic nerviosos de su rostro, las dificultades de su lengua traposa, las muestras todas de aquella garra implacable adueñada en su cerebro que va apretando y apretando hasta hundirlo en las sombras? [...] No es posible que un actor lleve al teatro mayores detalles, estudio más profundo de un personaje, concepción más maravillosa del realismo escénico. [...] Era un triunfo pleno, absoluto, en que iban de la mano el genio del escritor noruego que concibió el horror de aquel cuadro de la vida moderna y el gran actor español que encarnó su creación (s/a. (1909).Teatro Municipal: «Los espectros». Diario El Mercurio, 26 de junio).

Esta postura, inscrita en la polémica de entonces entre Stanislavski y Meyerhold, Jarry y Antoine, y recién antes, la Bernhardt y Guitry con Talma y Coquelin, ponen el acento en los modos de «vivir con verdad» en el escenario al personaje: ¿se trasluce el «hombre de la naturaleza» (Iris) en escena, o se esconde tras ella? Sarah Bernhardt, maestra indiscutible cuya voz aún se escucha en el medio, lo dilucida:

He oído decir a contemporáneos de Talma que este actor no se emocionaba jamás y que enseñaba a sus alumnos jóvenes el dominio de todas las pasiones que debían exteriorizar. Coquelin sostenía este aserto con aspereza, y estoy convencida de que se debe a este método el que nunca pudiera despertar el entusiasmo de su auditorio en las escenas patéticas que tanto le agradaban. [...] Yo he rozado la muerte real en mis muertes diferentes: en ocasiones he necesitado más de una hora para recuperar la vida. Tenía el cerebro anémico, el corazón sin latir, el pecho sin aliento; pero he sabido conservar la dosis de voluntad necesaria para recuperar mi verdadera personalidad, del mismo modo que hay que conservar suficiente sangre fría para no olvidar el papel ni la escenificación (Bernhardt, 1994: 50-1).

A partir de un estilo teatral que busca fusionar escena/vida, el espectador de este tiempo prefiere mantener la ilusión de verdad (es vida «real», no teatro), no romper el hechizo, no volver a reconocer el cuerpo del actor sino permanecer en el cuerpo del personaje. ¡Viva el actor completamente muerto! Esto, porque la muerte era un enigma y un misterio que subyacía a las corrientes espiritualistas de la época, ya sea las espiritistas (Vicuña, 2006), las teosofistas, las místicas, las oscurantistas, las ocultistas, y por qué no, también las corrientes cristianas. Y, junto con la muerte, se valoraban aquellos estados psíquicos y experiencias que rozaran el misterio y el éxtasis. Qué mejor que el teatro para experimentarlo, en al menos dos de sus vertientes dominantes: el simbolismo y el naturalismo científico, aún no plenamente desprendido del romanticismo. Así lo atestigua, en relación al actor Nicolás Carrera, la o el crítico Gabry Rivas (1912), en la revista teatral Musa Joven fundada por Luisa Fernández de García-Huidobro: ${ }^{49}$

Muchas veces yo no puedo aplaudirlo, tal sea la cantidad de éxtasis magnífico que me arrojaban sus miradas trágicas; y siempre que moría en escena [luego] sufría un verdadero

49 Madre de Vicente Huidobro y escritora de la generación de mujeres de «espiritualismo de vanguardia». 
desencanto al encontrarlo vivo. [...] Para mí, cuando un actor «se muere bien`, me quedo soñando con el supremo y misterioso fin.

Ese «excedente» de lo real es buscado por esta generación de mujeres de «espiritualismo de vanguardia», requiriendo, junto o más allá de una actuación con «verdad» científica, que sea visionaria, que abra una grieta que vislumbre lo por venir en la historia, en el desarrollo de los sujetos: «[Clara Della Guardia] me había dicho que el rol de Nora lo había estudiado <verazmente`, pero yo le diría que lo ha estudiado proféticamente» (Iris, 1910: 231-2). Sin duda, Echeverría piensa en su propia construcción de sujeto desde su «otro yo» que se expresa cuando firma como Iris, cuando escribe para la «liberación de femenina esclavitud», horizonte que ella presiente adviene en la cultura de Occidente.

Hay en Iris una extraordinaria capacidad de lenguaje sobre el cuerpo, que no solo se remite a la pulsión de «literaturizaciones» del cuerpo en la escritura de mujer (Oyarzún, 1992: 43) sino a un saber oral y escrito desarrollado por siglos en la cultura Occidental en relación a las performances actorales, tanto entre espectadores/críticos hombres como mujeres. Esto, porque desde el Antiguo Régimen, en la apreciación de un espectáculo teatral no importaba tanto la «novedad» de la intriga, ya que el texto era conocido por el público, ${ }^{50}$ pero sobre todo, por la repetición de los repertorios por las diferentes compañías en y a través del tiempo. Había un público «conocedor» de lo dramático, y su gran expectativa ante cada nueva escenificación por otro actor era dilucidar lo adecuado o genial de su estilo actoral, su creatividad en algunos pasajes especialmente esperados. Su ojo iba a la distinción, a la performance en todos sus detalles, articuladas con el texto, confrontados con las actuaciones ya conocidas. Fue así posible que Pedro Balmaceda Toro (A. de Gilbert) encabezara su crítica del Otello del italiano Emmanuel hacia 1889, aludiendo a los otras dos versiones que había visto, por los también grandes actores italianos Salvini y Rossi, o que Vicente G. Huidobro (1912) criticara la quinta versión vista por él de Tierra Baja en Chile, todas realizadas por compañías europeas:

El Manelich de Tierra baja es algo admirable. Yo había visto este drama cuatro veces, mas cuando lo dio Borrás, me pareció nuevo. Toda ponderación es poco, a veces con un gesto, con una mirada nos muestra toda una lucha horrenda que se desarrolla en el interior de su alma [...] entre las rocas y las breñas, tiene en el físico algo de animal, de felino. Ruge como fiera y acostumbrado a matar [...] sabe también matar los lobos [humanos] sanguinarios y crueles de la tierra baja (Huidobro, 1912).

\footnotetext{
50 Por la costumbre de leer teatro como literatura, publicado como folletines en la prensa en anticipación a su estreno. Iris leía los textos a viva voz con sus amigos antes de ver las obras en el teatro.
} 


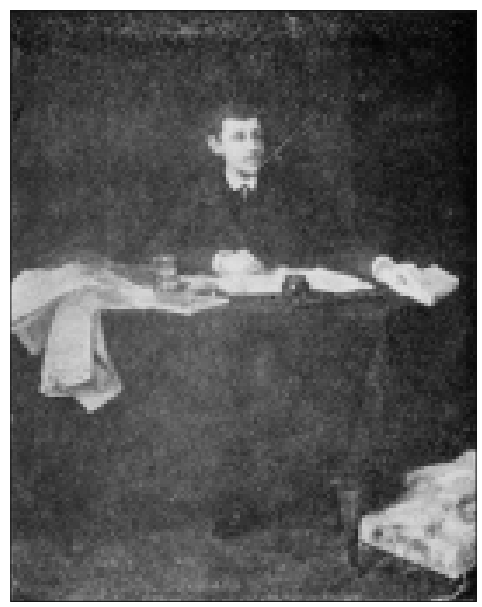

Pedro Balmaceda Toro. Retrato de Fernando Laroche. En (1889). Teatros, prosa desconocida de Rubén Darío.

Lo teatral manifiesta en este tiempo su posibilidad de actualizar un texto con sentidos y puntos de vista diferentes, según la interpretación y concepción escénica. Es una visión dinámica de lo teatral, que ve en el texto una forma abierta a la interpretación del lector y/o el espectador, una dialogicidad connatural a su organización lingüística en tensión de sentidos, no fijamente referenciales sino de fuerte contextualidad. Las transformaciones de los estilos actorales, desde el romántico al neo-romántico, el realista-psicológico, el naturalista o el simbolista, se iban apreciando en los cambios de interpretación de una misma obra, lo que era especialmente apreciable en clásicos como Hamlet. Por cierto, el crítico cumplía la función de esclarecer los nuevos códigos utilizados, ante la inercia o la incomprensión de los espectadores más «antiguos", formados en otros modos de actuación, para ellos canónicos. Así, en la propuesta de Hamlet de Tallaví, Iris reconoce en él una actuación de "naturalismo científico», que va articulando gestualidad (con especial énfasis en el manejo ocular) y voz con la situación psico-dramática del personaje: ${ }^{51}$

[Hamlet] ya está en presencia de la vida trascendental. [...] El siniestro fulgor del invisible [el fantasma del padre] se ha proyectado en aquel cerebro. El joven príncipe desde esa noche de visión se vuelve irónico, caprichoso y fantástico. [...] El señor Tallaví recorre ese camino magistralmente... sus ojos relampaguean, su frente se nubla, su cabello se descompone, sus pupilas se dilatan en vertiginoso vacío... [...] Hay lujo de matices en su tono. [...] Cuando Hamlet es llamado por su madre, el Sr. Tallaví pone en el diálogo una mezcla de ternura y de indignación, de crueldad y de compasión, que es de bellísima complejidad (Iris, 1910: 33-4).

\footnotetext{
51 Curiosamente, Pedro Balmaceda, en la crítica realizada dos décadas antes al Hamlet interpretado por Emmanuel, en contrario a Iris y Tallavi, aprecia el tono moderado, íntimo, de gestualidad oculta e insinuada que ocupa el actor, más cerca del realismo psicológico con matices simbolistas, consideradas por él como característicos del drama moderno.
} 


\section{IMPUGNACIONES A IRIS Y A SU VISIÓN DE LO TEATRAL EUROPEO}

[La obra de arte] en el instante en que nace, es fenómeno de ruptura.

[Es un] ‘hacer época; ; eso no es intervenir pasivamente en la cronología, es violentar el momento.

Henri Focillon, citado por Walter Benjamin en La dialéctica en suspenso

¿Qué capacidad de acogida del discurso nuevo o diverso tenía el espacio cultural santiaguino de la época, en relación a la construcción de género femenino realizada por Iris, vinculada a sus posiciones de vida, valóricas y estéticas a menudo vanguardistas y emancipatorias en el seno del habitus local? ¿Fue acaso ella una agente movilizadora: «el 〈agenciamiento〉 ha de ser encontrado justamente en esas junturas donde el discurso se renueva [...] la sagencia ha de ser encontrada en la posibilidad de resignificación abierta por el discurso» (Butler, 1995: 135).

Mi interés es llamar la atención sobre la dura lucha hegemónica que se libraba en ese tiempo, y que tomó a lo teatral europeo como un pivote entre la aristocracia local y los sectores mesocráticos, poniendo a Iris muchas veces en el ojo del huracán. Apuntaré a algunos de esos flujos producidos en torno a ella, ${ }^{52}$ comprobando que la escritura de estas mujeres pioneras fue «con sangre» (Rojo, citando a Gubar, 1997: 78), por la herida corporal y psíquica que les implicó, como también, agrego, por los dardos recibidos.

Un área fue la descalificación realizada por agentes masculinos, en una postura fóbica hacia la «mujer pública» o «la mujer intelectual», como el caso de las realizadas contra Iris por el crítico literario Pedro Nolasco Cruz: ${ }^{53}$ "son tan exaltados, destemplados y exagerados (sus comentarios teatrales), que parecen emociones de una señora provinciana que por primera vez hubiera asistido a representaciones dramáticas en el Teatro Municipal» (1926: 125). La infantiliza al ubicarla en una escala degradada de lo civilizatorio. Por su parte, Pateman sostiene: «las mujeres se encuentran con que su discurso o habla es persistente y sistemáticamente invalidado. Tal invalidación sería incomprensible si los dos sexos de hecho compartieran el mismo status como <individuos»» (1989: 218). ${ }^{54}$

La corriente más masiva, orgánica, y profundamente contestataria a lo que Iris valoraba en el teatro europeo en gira en Chile fue liderada por mujeres, en La Liga de Damas Chilenas pro Moralidad Teatral o también Liga contra la Licencia Teatral (1912-1917), presidida por Amalia Errázuriz de Subercaseaux. Afiliada a un movimiento de la Iglesia Católica, pone por delante a la mujer ${ }^{55}$ como defensora epónima de los valores espirituales, de la familia y de la pureza juvenil, contra el modernismo en las artes, en especial en el teatro. Se fundamenta así su misión en relación al teatro:

\footnotetext{
52 Este aspecto será profundizado como continuación de este Proyecto Fondecyt, en el ensayo «Discursividades y cuerpos en disputa: mujer, modernidad y censura ante el teatro europeo en Chile durante la Belle Epoque».

53 El comentario fue realizado antes de 1918 y es reproducido por Cruz en 1926 dentro de una compilación de críticas. La cita la debo a Subercaseaux (2001: 31).

54 Echeverría presentó una querella contra Cruz por sus dichos, la que fue desestimada infringiéndole una humillación adicional por aceptar este como sólo interlocutor a una voz masculina (el marido).

55 Digo «pone por delante a la mujer» porque en la sesión inaugural, sólo hablaron hombres: el escritor Joaquín Díaz Garcés, el alcalde de Santiago Ismael Valdés Vergara y el político conservador Joaquín Walker Martínez. Es miembro del directorio el Arzobispo de Santiago, y la sesión inaugural se realizó en dependencias del Diario El Mercurio.
} 
En vista de la apremiante necesidad de sujetar el desborde de la inmoralidad en los teatros, la Liga de señoras tomará como primer trabajo el combatir con todas las fuerzas [...] ese lamentable y pernicioso exceso. Será pues, Liga contra la licencia teatral [...] de espectáculos que tienden a prostituir el arte y la belleza, haciéndolos degenerar en una manifestación desvergonzada del vicio y del impudor. (S/A. (1912) Lo que hará la Liga. Boletín El Eco 1: $1,1^{\circ}$ de agosto)

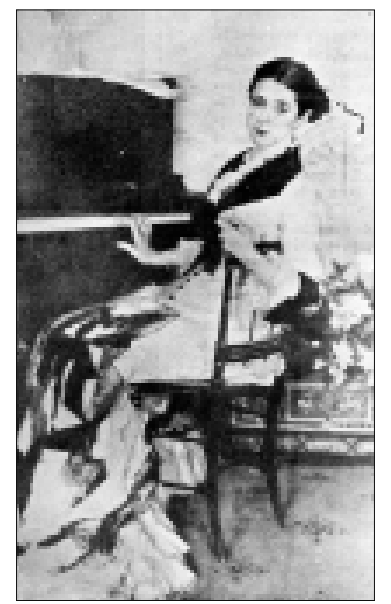

Amalia Errázuriz de Subercaseaux, presidenta Liga de Damas Chilenas. Retrato de J. Sarjent. Revista La Semana llustrada 5, 1902.

La Liga publica El Eco de la Liga de Damas Chilenas (1912-1915), luego La Cruzada (1915-1917), cuyo lema era «Dios, Patria y Familia». Es un ámbito de formación de algunas mujeres conservadoras como redactoras, y genera una red nacional de mujeres contra el teatro «inmoral»: en 1915 contaban con dos mil suscriptoras y en 1917, con 35 ligas locales hasta en las ciudades más pequeñas del país.

Junto con calificar obras teatrales en «lista negra» para que no fueran vistas por el público, su objeto es hacer ver que «la Iglesia [...] ha tenido palabras de dura condenación para todo espectáculo escandaloso, donde se respire atmósfera de paganismo y sensualidad o se vea el hogar prostituido, lo que bien pudiera llamarse escuela de perversión» (1916, La Cruzada 88). Este movimiento considera al teatro de autores como Maeterlinck e Ibsen, que Iris ha apoyado con fervor y argumentos en su propia cruzada de apertura, como el origen de este desquiciamiento, con lo que se la cuestiona indirectamente:

La influencia del teatro germánico y noruego introdujo la tesis y el simbolismo en el teatro español. A partir de este momento se acentuó la decadencia de nuestra escena, de la que se ha pretendido hacer cátedra para justificar todas las transgresiones morales, para predicar todas las utopías sociales (1915, La Cruzada 68). 


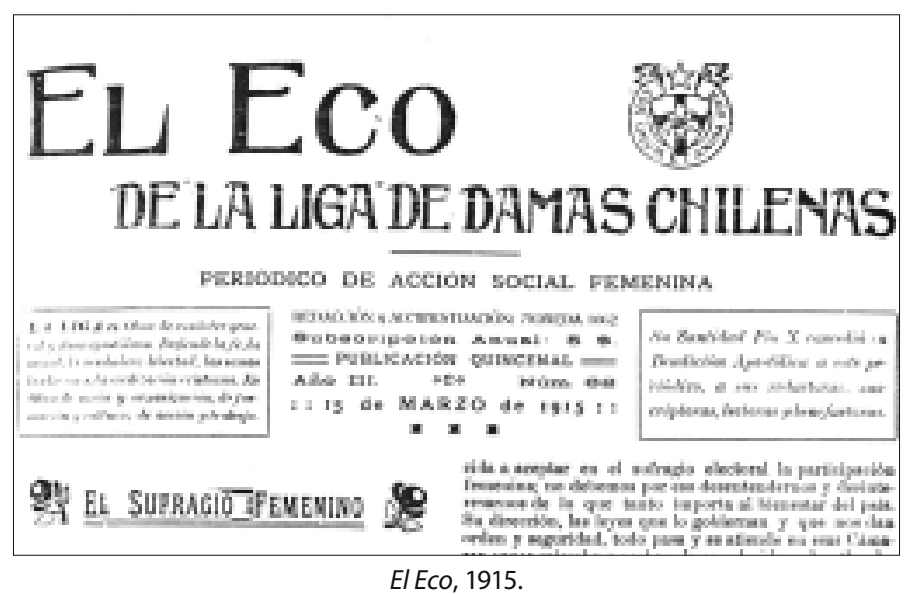

Con este ejemplo, quiero evidenciar la fuerza y virulencia de los flujos de agenciamiento en direcciones opuestas que corrían en torno a lo teatral, estando las contrarias a Iris articuladas con todas las instancias de poder vigentes: el Estado, la Iglesia, la clase dominante (aristocracia) y su prensa (El Mercurio y El Ilustrado).

A tres años de iniciada la Liga, Echeverría lidera organismos de mujeres a favor de sus mismos flujos de «liberación de femenina esclavitud», entendida como integración de la mujer a la corriente cultural y progresista mundial, en re-edición en Chile de similares organizaciones de mujeres estadounidenses y europeas.

En julio de 1915, funda con Amanda Labarca y otras escritoras el Círculo de Lecturas de Mujeres, ${ }^{56}$ dedicado a comentarios crítico-literarios, lectura de poesía y escritos femeninos, ${ }^{57}$ audición de música, etc. y realizar concursos de literatura de mujeres. A estas alturas hay quienes ponderan a Echeverría como «la primera pluma femenina de América» (Fémina (1915): Zig-Zag). En 1916, este Círculo adscribe y se integra al Club de Señoras, en cuya sede realizan conferencias, talleres, cursos, presentaciones teatrales, convivencias. Iris integra su directorio. ${ }^{58}$

$\mathrm{Al}$ año de creado este Club, surgieron divergencias en cómo enfocarlo. Si Echeverría en su artículo en La Nación "Signo de los tiempos» (1917) celebra como un gran progreso de las mujeres haber comentado en el Círculo de Lectura de Señoras a Rolland, Maeterlinck, Bergson, Franklin y Emerson, la historia oculta es otra. El crítico Alone, cercano amigo de Iris, en su Diario Intimo comenta: "iLas ovejitas del círculo temen perder su inocencia si les hablan de Maupassant!» (2001: 28 y 30-1), refiriéndose a lo dicho por Iris de sus detractoras: «Estas mujeres tontas, que se cuidan tanto la inocencia. Como si temiera perderla yo, que soy casi centenaria!». Alone completa el cuadro relatando: «Recibí carta impertinente de Roxane ${ }^{59}$ contra «esas mujeres»», y agrega que supo que «Roxane había falsificado un acta del Directorio del Círculo para hacer tratar a Maupassant. Bien hecho».

56 Llamado inicialmente Sociedad Femenina de Escritoras.

57 En su Primera Reunión Extraordinaria, leyó sus versos la joven poetisa Gabriela Mistral.

58 Esta institución funciona hasta alrededor de 1925.

59 Elvira Santa Cruz de Ossa, escritora, dramaturga, periodista. 
La división en el Club de Mujeres es abierta: hay «esas» mujeres contra «estas mujeres», «nosotras» «las otras», en fricción discursiva. Las disensiones que pudieron provocar entre ciertas mujeres las opiniones de Iris en su crítica teatral entre 1908-1910, en esta década más tarde afloran en público. Ejemplar es cuando Iris reitera en El Club los postulados sobre Ibsen y Casa de Muñecas que sostuviera en 1909, siendo rebatida por una «amiga» oculta en el anonimato y vía autoridad masculina, citada (¿por encargo?) por un periodista.

Sus afirmaciones en el campo de la ética por unas tildadas de geniales y altísimas; por otras, de disolventes y anárquicas. [...] Una señora de gran cultura y brillante espíritu nos condensó su parecer [...]: siento en forma irresistible que la filosofía de Ibsen, tal como se ha expuesto entre nosotros, significa la ruina y muerte del hogar, de la familia y de cuantas instituciones hemos aprendido a querer y a respetar. Por esto condeno la obra revolucionaria que ha iniciado mi distinguida amiga al defender las audacias de un poeta (S/A (1917): Revista La Tribuna Ilustrada 20). ${ }^{60}$

Las editoriales de la Revista Familia, lugar donde se inició el Club de Lecturas, acusa a las mujeres que discuten a Maeterlicnk y a Bergson de "ciega presunción» y proponen una vía alternativa

No comprendemos que así se derroche el talento y la paciencia, descubriendo [...] tendencias de almas que no nos interesan, pues no son de nuestra raza y no tienen nuestros gustos y costumbres. Tiempo es que tengamos el orgullo de lo que somos. [...] que conozcamos bien nuestra historia y el carácter de los hombres que la hicieron. [...] Conoceríamos a los notables escritores que dieron lustre a la notable literatura chilena (1917. Editorial. Familia 89).

La paradoja cierra su círculo: habiéndose constituido estas mujeres en 1915 para ampliar, promover, dar espacio público a la obra literaria, ensayística y crítica de la mujer chilena y de los representantes de la cultura europea considerada de vanguardia, dos años después algunas proponen volver a centrarse en lo que sí tiene valor reconocible: el carácter de los hombres que hicieron la nación (¿políticos, estadistas, militares?) y los escritores (en masculino) que dan gloria a la literatura chilena. No, por cierto, la escrita por mujeres. El atendible tema del realce de la creatividad nacional (Iris criticó solo creadores europeos, salvo excepciones como la Mistral y Pedro Prado) se cierra para algunas en un nacionalismo patriarcal: los escritores y próceres de la nación, oficialmente canónicos.

\footnotetext{
60 Otra mujer, oculta bajo el seudónimo de Sombra declara en 1917 en Revista Zig-Zag 646, a propósito de Iris, que «si me dieran a elegir entre ese Club (de Señoras) brillante poblado de estrellas, y entre la Liga de Damas Chilenas, yo creo que me quedaría con esta última. ¿Por qué? [...] Yo amo y respeto antes que nada en la mujer a la madre y a la esposa: ellas están en mi simpatía por sobre todos los destellos de la inteligencia».
} 


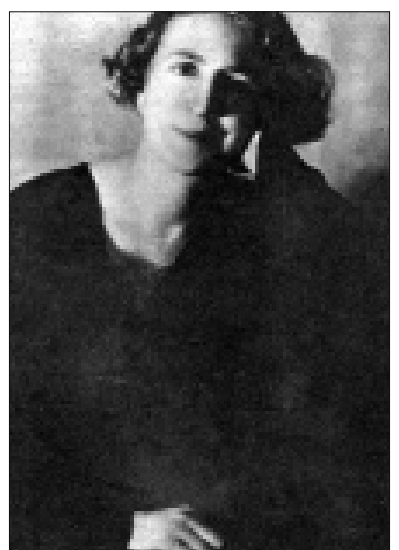

Inés Echeverría Bello. En Revista Zig-Zag 1581, 1935.

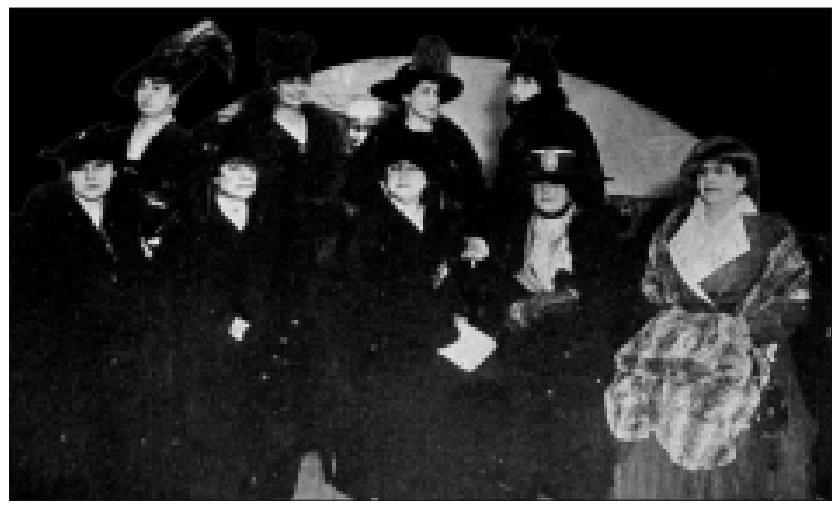

Directorio del Club de Señoras En revista Zig-Zag 601, 1916.

Los vaivenes eran fuertes y aún quedaba mucho paño por cortar para que la ampliación del imaginario y la práctica femenina y de las artes fuera acogida por una corriente considerable de mujeres y hombres de su tiempo, en especial, de las vinculadas a la clase dominante en la vertiente católica tradicional. No es raro que, ya desde 1917, en especial a través de sus artículos en el Diario La Nación y en sus conferencias, Iris incursionara, además de en temas de teatro y arte, en políticas públicas, y que adhiriera públicamente a la candidatura y gobierno de Alessandri Palma (1920), líder de una apertura popular mesocrática que puso término a los gobiernos oligárquicos en Chile.

\section{REFERENCIAS}

S/A. (1910). Diario El Mercurio. 3 de marzo.

S/A. (1910). Teatro Nacional. Diario El Mercurio, 17 de noviembre.

S/A. (1917). Editorial. Revista Familia 90: p. 1. 
S/A. (1917) .Opiniones Divergentes. Revista La Tribuna Ilustrada 20, 10 de noviembre. Alone (Hernán Díaz Arrieta). (2001). Diario íntimo (1917-1947). Santiago: Zig-Zag.

Balmaceda Toro, Pedro (A. de Gilbert). (1889). Estudios y ensayos literarios. Santiago: Cervantes.

Barrios, Eduardo. (1916). Un drama de Eduardo Barrios. Entrevista de Daniel de la Vega. Revista Zig-Zag 590.

Benjamin, Walter. (1997). La dialéctica en suspenso. Fragmentos sobre la historia. Santiago: Lom-Universidad Arcis.

Berenguer, Ángel. (1983). Teatro europeo de los años 80. Barcelona: Laia.

Bernhardt, Sarah. (1994). El arte del teatro (1923). Barcelona: Parsifal.

Bhabha, Homi K. (1994). The location of culture. Londres y Nueva York: Routledge.

Bourdieu, Pierre. (1995). Las reglas del arte. Génesis y estructura del campo literario. Barcelona: Anagrama.

Butler, Judith. (1995). For a careful reading. En Seyla Benhabib et al. Feminist contentions. A philosophical exchange (pp. 127-143). Nueva York: Routledge.

Carlson, Malvin. (1993). Theories of the theatre. Ithaca and Londres: Cornell University Press.

Concha y Castillo, F. A. (1909). Musa chilena - a María Guerrero. Diario Ilustrado, 10 de enero.

Cruz, Pedro Nolasco. (1926-1940). Estudios sobre la literatura chilena. Tomo III, Santiago.

De Laurentis, Teresa. (1988). Displacing hegemonic discourses: reflections on feminist theory in the 1980s. Revista Inscriptions, 3/4, 136.

Echeverría, Inés (IRIS). (1916). Pasado y presente de la mujer, Revista Ziz-Zag, 18 de noviembre.

- (1918). La mujer ante el código civil. Diario La Nación, 23 de junio.

. (2001). Alma femenina y mujer moderna. Antología. Ed. y Estudio preliminar, Bernardo Subercaseaux. Santiago: Consejo Nacional del Libro y la Lectura/ Editorial Cuarto Propio.

Echeverría Bello, Inés. (2005). Memorias de Iris. 1899-1925. Santiago: Aguilar.

Fémina. (1915). Una sociedad de cultura Femenina organizada en la revista Familia. Revista Zig-Zag 542, 10 de julio.

Foucault, Michel. (1979). What is an Author? En Josué V. Harari. Ed. Textual strategies (pp. 108-149). Ithaca: Cornell University Press. . (1992). Microfísica del poder. Madrid: La Piqueta. . (1997). ¿Qué es Crítica? En Ed. Sylvère Lotringer \& Lysa Hochroth. The politics of truth. (pp. 23-82). New York: Semitext(e).

Giella, Miguel Ángel. (1994). De dramaturgos: teatro latinoamericano actual. Buenos Aires: Corregidor.

Hennessy, Rosemary. (1993). Materialist feminism and the politics of discourse. Nueva Cork y Londres: Routledge.

Habermas, Jürgen. (1999). Historia y crítica de la opinión pública. Transformación estructural de la vida pública. Barcelona: Gustavo Gili.

Hobsbawm, Eric. (1998). La era del imperio, 1875-1914. Buenos Aires: Grijalbo Mondadori.

Hozven, Roberto. (2001). Alegorías identitarias en cuatro ensayos chilenos. Anales de Literatura Chilena Año 2, 2: 207-219.

Huidobro, Vicente. (1912). Borrás. Revista Musa Joven, año 1, Julio. 
Hurtado, María de la Luz. (2007). Actores europeos en los teatros de la Belle Epoque chilena: discursos locales en torno a modernidad, identidad y género. Revista Apuntes 129: 100-135.

Iris. (1910). Emociones teatrales. Santiago: Barcelona.

Kristeva, Julia. (1999). Sentido y sinsentido de la rebeldía. Literatura y psicoanálisis. Santiago: Cuarto Propio.

Memmi, Albert. (1983). Retrato del colonizado precedido por el retrato del colonizador. Buenos Aires: De la Flor.

Miller, Arthur. (1988). El desafío trágico actual. Revista Apuntes 97: 133-141.

Morales, Leonidas. (2001). La escritura de al lado. Géneros referenciales. Santiago: Cuarto Propio.

Nómez, Naín. (1997). Gabriela Mistral y la poesía femenina de comienzos de siglo en Chile. En Gastón Lillo y J. Guillermo Renart (eds.), Re-leer hoy a Gabriela Mistral. Mujer, historia y sociedad en América Latina (pp. 83-95). Ottawa: University of Ottawa.

Oyarzún, Kemy. (1993). Género y etnia. Acerca del dialogismo en América Latina. Revista Chilena de Literatura 41: 33-45.

Palomera, Adriana y Alejandra Pinto (compiladoras). (2006). Mujeres y prensa anarquista en Chile (1897-1931). Santiago: Espíritu Libertario.

Pateman, Carole. (1989). Feminism and democracy. En The disorder of women. Democracy, feminism and political theory. (pp. 210-225). Stanford: Stanford University Press.

Pavis, Patrice. (2001). Del silencio en las estructuras. Revista Apuntes 119-20: 174-184. (1985). Voix e image de la scene. Vers une semiologie de la réception. Villenueve d'Aseq: Presses Universitaires de Lille.

Pérez, Manuel. (2004). Hacia una teoría de la crítica teatral. Revista Teatro XXI 18: 14-21.

Picó, Joseph. (1992). Introducción. En Modernidad y postmodernidad (pp. 13-50). Madrid: Alianza.

Rojo, Grínor. (1997). Mistral en la historia de la mujer latinoamericana. En Gastón Lillo y J. Guillermo Renart (eds.), Re-leer hoy a Gabriela Mistral. Mujer, historia y sociedad en América Latina (pp. 53-82). Ottawa: University of Ottawa.

Rivas, Gabry. (1912). Próxima temporada teatral. Revista Musa Joven 6, $1^{\circ}$ de octubre.

Sennett, Richard. (2002). El declive del hombre público. Barcelona: Ediciones de Bolsillo.

Simmel, Georg. (2001). El comediante y la realidad (1912). París: Circe.

Sombra. (1917). Lejos de las obscuridades sectarias y las limitaciones estúpidas. Revista Zig-Zag 646, 7 de julio.

Szondi, Peter. (1994). Teoría del drama moderno. En Teoría del drama moderno, pp. 11174. Barcelona: Destino.

Veneros, Diana y Paulina Ayala. Dos vertientes del movimiento pro emancipación de la mujer en Chile: feminismo cristiano y feminismo laico. En Diana Veneros (ed). Perfiles revelados Historias de mujeres en Chile Siglos XVIII-XX (pp. 36-52). Santiago: U. de Santiago.

Vicuña, Manuel. (2006). Voces de ultratumba. Historia del espiritismo en Chile. Santiago: Taurus.

Wagner, Peter. (1994). A sociology of modernity. Liberty and discipline. USA and Canada: Routledge. 
Wollen, Peter. (2005). Salomé. Imágenes de pasión y poder. En Museo Nacional de Arte Reina Sofía (ed.), Salomé, un mito contemporáneo (pp. 65-88). Madrid: Ministerio de Cultura.

Recepción: agosto de 2008

Aceptación: octubre de 2008 